
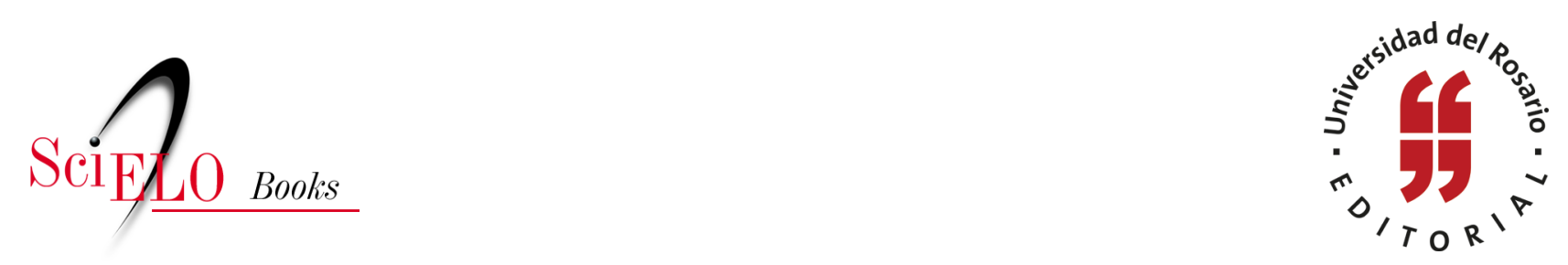

\title{
2. De la causalidad adecuada a la imputación objetiva en la responsabilidad civil colombiana Aplicación particular en la responsabilidad civil ambiental
}

\author{
Sergio Rojas Quiñones \\ Juan Diego Mojica Restrepo
}

\section{SciELO Books / SciELO Livros / SciELO Libros}

ROJAS QUIÑONES, S., and MOJICA RESTREPO, J.D. De la causalidad adecuada a la imputación objetiva en la responsabilidad civil colombiana Aplicación particular en la responsabilidad civil ambiental. In: AMPARO RODRÍGUEZ, G., and VARGAS CHAVES, I., ed. Perspectivas de responsabilidad por daños ambientales en Colombia [online]. Bogotá: Editorial Universidad del Rosario, 2015, pp. 2991. Textos de Jurisprudencia collection. ISBN: 978-958-738-644-8.

https://doi.org/10.7476/9789587386448.0003.

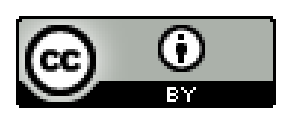

All the contents of this work, except where otherwise noted, is licensed under a Creative Commons Attribution 4.0 International license.

Todo o conteúdo deste trabalho, exceto quando houver ressalva, é publicado sob a licença Creative Commons Atribição 4.0.

Todo el contenido de esta obra, excepto donde se indique lo contrario, está bajo licencia de la licencia Creative Commons Reconocimento 4.0 . 


\title{
2. De la causalidad adecuada a la imputación objetiva en la responsabilidad civil colombiana Aplicación particular en la responsabilidad civil ambiental
}

\author{
Sergio Rojas Quiñones* \\ Juan Diego Mojica Restrepo**
}

El nexo de causalidad, entendido como la "necesaria conexión fáctica que debe existir entre la acción humana y el resultado dañoso producido” (Pizarro, 2006, p. 87), es uno de los presupuestos fundamentales para la prosperidad de cualquier pretensión indemnizatoria en el marco de la responsabilidad civil. No en vano, se trata de uno de aquellos elementos que resultan imprescindibles en tratándose de cualquier tradición jurídica, ya sea en el derecho de daños continental (civil law) o en el anglosajón (common law). ${ }^{1}$

* Abogado de la Pontificia Universidad Javeriana; magíster en Derecho de Daños de la Universidad de Girona (España). Miembro activo del Instituto Colombiano de Responsabilidad Civil y del Estado, del Centro de Estudios de Derecho Privado de la Pontificia Universidad Javeriana e investigador del Grupo de Investigación en Derecho Privado; profesor de la cátedra de Responsabilidad Civil de la misma universidad, de Obligaciones en la Universidad de los Andes y de varios programas de posgrado; asociado de la firma Salazar, Pardo \& Jaramillo Abogados. Ha escrito varios textos académicos relacionados con la responsabilidad civil y el derecho de obligaciones.Correo electrónico: srojas@spjlaw.com

** Estudiante de X semestre de la Pontificia Universidad Javeriana. Director de la revista Universitas Estudiantes; miembro del Semillero de Investigación en Derecho Procesal y del Grupo de Investigación en Derecho Civil en las líneas de investigación en Responsabilidad Civil y Contratos de la Universidad Javeriana. Actualmente está vinculado a Salazar, Pardo \& Jaramillo Abogados. Correo electrónico: judimore87@hotmail.com

${ }^{1}$ Sobre la similitud en la concepción de la causalidad en el common law y el civil law, Eric Engle expone: "Causation is one of the most complex and unclear aspects of tort law. However, common law and civil law reach surprisingly similar legal solutions about the problem of causation despite the fact that the problema of causation in tort law is, at least in theory, factually indeterminate. Legal convergence in tort law was not merely a pragmatic result of economic facts. It was also implicit in common philosophical presuppositions about causality in national law which influenced tort law in both common law and civil law countries and provided the basic 
Colombia no es la excepción a este aserto. El artículo 2341 del Código Civil indica que "[e]l que ha cometido un delito o culpa, que ha inferido daño a otro, es obligado a la indemnización (...)", de donde se colige entonces que solo a quien le resulte imputable la conducta, a título de acción u omisión, le es atribuible la responsabilidad. Así, quienes no son los detonantes causales del resultado no pueden, en modo alguno, ser obligados a indemnizar o, puesto en otros términos, solo quien ha dado lugar al daño - lo ha causado - tiene legitimación pasiva para ser condenado.

Lo anterior no es sino lógica consecuencia de la estructura misma de la responsabilidad y, más allá de eso, de la filosofía moral que subyace a ella. Ciertamente, la consecuencia natural de la libertad que se le reconoce a todo individuo por el solo hecho de ser persona supone, entre otras, que ese individuo se apropie de sus acciones y de los resultados a que estas conducen. En ese orden de ideas, solo podemos reconocer la idea de libertad si entendemos que, como agentes, somos el dominus de lo que hacemos o dejamos de hacer y, de contera, somos responsables por sus resultados. Este es el presupuesto de la teoría de la agencia que, se itera, nos reconoce como libres pero, a su turno, como responsables. Naturalmente esta idea tiene una contracara que también debe ser clara: así como somos dueños - y, por ello, responsables - de nuestras acciones, no lo somos de las acciones de otros; lo que haga o deje de hacer un tercero no compromete nuestra responsabilidad por la sencilla razón de que no somos dueños de tales acciones; ese es el presupuesto fundamental de la libertad.

Pues bien, todo ello se hace patente en la exigencia del vínculo de causalidad. La mejor expresión de que solo somos responsables por los resultados que causemos es la causalidad que, en ese orden de ideas, se erige como la versión jurídica del principio moral de la agencia, en virtud del cual, como somos dueños de nuestras propias acciones, somos también dueños de sus resultados. Allí estriba la importancia de la causalidad. Con todo, si bien resulta indiscutible que solo quien con su actuar ha causado un daño deberá repararlo,

superstructural framework for legal convergence" (Engle, 2009, p. 3). Sobre la causalidad en el common law, el profesor norteamericano Larry Alexander afirma: "[T]he fact that a particular defendant's conduct was a 'but for' cause of an injury to a particular plaintiff, which fact is a necessary condition for the plaintiffs recovering corrective damages from the defendant, is the fundamental building block of all tort law. Regardless of what other conditions, if any, tort law imposes as necessary for plaintiff's recovering from the defendant - proximate causation, foreseeability, negligence or recklessness or intent, design defect-a 'but for' causal link between the plaintiffs injury and the defendant's conduct is essential. No causation, no tort" (Alexander, 1987, p. 1). 
esta claridad se pierde en una nube de complejidad e indeterminación al momento de establecer, en concreto, el vínculo causal entre el perjuicio irrogado y el actuar de quien es sindicado como agente dañador.

Al respecto señala Obdulio Velásquez que

el sentido común se niega a admitir que la existencia de un daño sea soportada por quien no ha influido en la realización del mismo. Entonces se necesita una relación causa-efecto entre el acto humano y el daño que se produce, es decir, la causación del daño por el agente dañino es necesaria para que se configure responsabilidad civil, además del daño y la culpa. En ocasiones, la identificación de la causa no ofrece especiales dificultades para el operador del derecho, pero en otras, especialmente si concurren muchos factores que podrían ser causa de ese resultado dañoso, el determinar a la luz del derecho cuál o cuáles factores deben recibir la categoría de causa ofrece serias dificultades conceptuales y prácticas (2009, p. 461).

Estas dificultades, como es de sobra conocido, tienen su punto de partida por fuera del derecho, en la medida en que se remiten al mundo de la física y de la filosofía. Es así como tradicionalmente se ha identificado que la cuestión del nexo causal ofrece dificultades desde la perspectiva conceptual (¿qué es la relación causa-efecto?), metafísica (¿qué es lo que ocurre en el mundo cuando aludimos a una conexión causal?) y epistemológica (¿cómo conocemos la causalidad?), lo que ha conducido a que, desde el empirismo, se acuñen las más diversas teorías para explicar este fenómeno, cada una situada en consideraciones diferentes y en el replanteamiento de los postulados de su predecesora: las teorías regularistas, las de los juicios contrafácticos, las probabilísticas y las de los procesos fijos, por mencionar solamente los géneros más destacados.

En el derecho, esta dificultad también se ha hecho patente, tanto en la esfera penal como en la civil. En lo que concierne a esta última, el derecho de daños ha debido enfrentarse a las conocidas problemáticas de la sobredeterminación causal, la incertidumbre en el nexo (causalidad alternativa con incertidumbre en el agente, causalidad alternativa con incertidumbre en la correspondencia agente-víctima, víctimas no identificadas e incremento de riesgo, por citar sus expresiones más representativas), la causa potencial, la causalidad alternativa hipotética, entre otras más. Como es obvio, las soluciones han sido disímiles y se 
han debatido entre los extremos de las reglas de preponderancia ('more probable than not' o reglas de 'todo o nada') y proporcionalidad o probabilidad, como se observa en los Principios de Derecho Europeo de la Responsabilidad Civil. ${ }^{2}$ Esto ha llevado entonces a que la causalidad se erija como uno de los elementos de más difícil estudio al momento de adelantar un juicio de responsabilidad civil. ${ }^{3}$ Como lo indicara recientemente un reconocido autor:

\footnotetext{
${ }^{2}$ En relación con las nuevas tendencias en materia de causalidad, no debemos registrar el pronunciamiento del 16 de mayo de 2011, en el que la Sala de Casación Civil de la Corte Suprema de Justicia indicó que "... admitida la variedad extremada de situaciones, a las concepciones de la prueba del nexo causal (causalidad eficiente, adecuada, equivalencia de condiciones, etc.) y mecanismos tradicionales de facilitación (prueba prima facie, Anscheinsbeweis der Kausalität, res ipsa loquitur, id quod plerumque accidit, causalité virtuelle, inversión de la carga probatoria, presunciones hominis), el derecho comparado plantea soluciones disímiles de bastante envergadura, ad exemplum, los juicios de probabilidad parcial (causalité partielle o causalitá raziale), posible (mögliche Kausalität Prinzip), probabilística (probabilistic causation approach, causalitá probabilística), conexión probable, predicibilidad o proporcional (proportional causation approach), la causalidad disyuntiva, alternativa, anónima, sospechada, colectiva o conectada, la 'responsabilidad colectiva' (Ley 25675, Argentina) o la 'responsabilidad anónima', dándose un grupo presunto de responsables, tomándolos in solidum a todos. En sentido análogo, algunas legislaciones disciplinan presunciones de causalidad cuando de las circunstancias fácticas del caso concreto un comportamiento es idóneo para causar el daño, se presume efectivamente causado por éste sin requerir la prueba cierta del nexo, verbi gratia, la idoneidad específica de una planta para producir el daño será apreciada conforme a los detalles concretos de su ejercicio, operaciones, equipo utilizado, naturaleza y concentración de las sustancias liberadas en el medio ambiente, las condiciones atmosféricas, la hora y lugar del daño, y bajo cualquier otra circunstancia que, en su contexto fáctico, pueda proporcionar evidencia a favor o en contra de su ocurrencia, salvo si obtenidas todas las autorizaciones para funcionar, no se encuentra ninguna anomalía en su ejercicio (art. 305 del Dlgs.152/2006, Italia). El §6 de la Ley alemana del Medio Ambiente (UmwelthG, de 10 de diciembre de 1990) previene la presunción de causalidad cuando la instalación se considera 'apropiada'o 'intrínsecamente adecuada' para generar el daño, en cuyo caso probada la adecuación, compete al presunto autor acreditar que no es su causa o enervar la presunción demostrando su idónea utilización, ausencia de anomalías en su funcionamiento y el cumplimiento de los 'deberes de utilización' $(2, \S 6)$ u otra circunstancia 'apropiada' (\$7),y la jurisprudencia americana aplica además de las reglas but for test (condicio sine qua non), las relativas al factor sustancial conforme a un test de probabilidad, 'balance de probabilidades' (balance of probabilities), precisándose en el marco de circunstancias fácticas la probable causación del daño o su no ocurrencia (more probable than not, more likely than not), acorde a la preponderancia del hecho (preponderance of the evidence), el criterio more probable than not, 'juicio dentro del juicio'(trial within the trial; procès-dans-le-procès) o juicio probabilístico fundado en un conjunto serial de casos tomando las actividades generales y las particulares a apreciar, así como la causalidad alternativa..." (Corte Suprema de Justicia, sentencia del 16 de mayo de 2011) (Díez-Picazo, 1989, p. 338).

${ }^{3}$ Con relación a esta dificultad, se ha dicho en el derecho francés: "La causalité est une notion qui fait presque consensus au sien de la doctrine français... sur sa difficulté: la notion de causalité est une redoutable sirène: elle égare volontiers ceux que sa subtilité séduit et qui cherchent à la pénétrer jusque dans ses mystères intimes'. Il est certain que l'analyse de la causalité n'a guère tenté les auteurs français, pénétrés qu'ils étaient de la vanité de leurs recherches face au pragmatisme de la jurisprudence', et l'on déplore ses 'affres', ou ses 'arcanes'. La causalité serait 'le problème le plus complexe de la responsabilité civile', un 'redoutable mystère', une notion 'd'une extrême
} 
[L]os hechos que provocan una modificación en el mundo externo no siempre se presentan con claridad meridiana que permita dilucidar fácilmente cuál es la causa jurídica de un determinado efecto dañoso. De manera frecuente, denotan complejidad, motivada por la concurrencia de múltiples circunstancias distintas que actúan como condición del resultado dañoso. Determinar cuál de esas condiciones es la causa del resultado dañoso producido constituye, de tal modo, una cuestión vital y compleja, que ha desvelado no sólo a juristas sino también a filósofos (Pizarro, 2006, p. 92).

No es gratuita entonces la preocupación que asalta a los estudiosos del derecho de daños ante la incertidumbre existente frente a este presupuesto fundamental de la responsabilidad civil. ${ }^{4} \mathrm{~A}$ las complejidades físicas y naturalistas, se suma el hecho de que sin una causalidad clara no es posible la imputación del daño a su autor, pues no se podrá develar la relación causaefecto que da el lugar de deudor de la obligación indemnizatoria al agente dañador. Tampoco se alcanzará a delimitar el alcance de la indemnización; en otras palabras, se desconocerán cuáles son los perjuicios que ciertamente se han derivado de la conducta dañosa.

Pues bien, para intentar facilitar esta tarea de averiguar quién es el obligado a reparar el daño sufrido por cierta persona, se han desarrollado una variedad de teorías jurídicas. La teoría de la equivalencia de las condiciones, la teoría de la causa próxima, la teoría de la causa eficiente, la teoría de la causalidad adecuada y, más recientemente, la teoría de la imputación objetiva, se han encargado, con diferentes criterios, de permitir la determinación del agente

difficultê,', 'toujours irritante', un problème 'insoluble'; 'l'un des champs de discussion les plus difficiles et aussi les plus confus de la doctrine', et 'l'une des questions les plus insaisissables de notre droit'; sa théorisation serait une 'recherche absolument vaine" (Quézel-Ambrunaz, 2010).

${ }^{4}$ Con todo, valga resaltar, como lo hace Pizarro, que "el papel protagónico de la relación de causalidad en el derecho de daños se ha agigantado en las últimas décadas, luego de haber permanecido ignorado o relegado a un plano secundario por la doctrina civilista que, a lo largo de un prolongado período de la historia, resolvió ' $[. .$.$] las dudas acerca del alcance del nexo causatorio [...] acudiendo en situacio-$ nes concretas a pautas empíricas [...]', impregnadas de una elevada dosis de intuición y del particular sentimiento de justicia de cada magistrado. Recién a mediados del siglo pasado, el hombre de derecho logró formular la teoría de la relación de causalidad sobre bases verdaderamente científicas, dotándolas de autonomía conceptual y funcional, y la independizó de los demás presupuestos de la obligación de resarcir" (2000, p. 255). 
generador del daño y la delimitación de cuáles son los daños conectados con su actuar y, de contera, el alcance de su responsabilidad.

En Colombia, la jurisprudencia de la Corte Suprema de Justicia en su Sala de Casación Civil ha acogido la teoría de la causalidad adecuada como herramienta para señalar cuándo una actuación ha sido la causa de un daño y, a partir de ello, condenar a su autor a reparar el perjuicio irrogado. Por esta razón, el presente estudio pretende exponer las limitaciones que se le han atribuido a la teoría de la causalidad adecuada, que, por fundamentarse en parámetros abstractos como las máximas de la experiencia, el sentido común y la previsibilidad, pueden llegar a enervar la indemnización de ciertos daños que, de acuerdo con la justicia, deberían indemnizarse.

Se demostrará que la inexistencia de una distinción entre causalidad de hecho y causalidad de derecho —o, más propiamente, entre causalidad e imputación objetiva - en el sistema jurídico nacional ha llevado a que el criterio de la adecuación (y, de contera, el parámetro del observador óptimo y la prognosis póstuma) sea adoptado como una teoría de la causalidad fáctica y no de la imputación propiamente dicha, que es como, en principio, debería figurar. Ello ha acarreado una serie de inconvenientes, por ejemplo, por solapamiento de las categorías y por reducción al absurdo en lo tocante con la causalidad fáctica.

Es por ello por lo que como propuesta se presentará una teoría que propende por la diferenciación entre una causalidad de hecho y una causalidad de derecho, en aras de determinar acertadamente cuándo se configura la relación causal. Con esta distinción se intenta superar los problemas achacados a la causalidad adecuada, para prevenir los resultados contraintuitivos que se presentan con su aplicación. Para la primera clase de causalidad propuesta, la causalidad de hecho, se recurrirá al juicio contrafáctico que proporciona la conditio sine qua non; este permitirá afirmar cuándo existe relación causa-efecto de un hecho frente a un daño, desde una perspectiva física o meramente naturalística. En cuanto a la segunda, la causalidad de derecho, se retomará el juicio de previsibilidad del que echa mano la teoría de la causalidad adecuada para lograr la imputación objetiva de un perjuicio a un agente.

Como es obvio, a esta teoría, como a todas aquellas que se encuentran en proceso de perfeccionamiento, se le ha identificado un conjunto de dificultades, como lo son la sobredeterminación y la indeterminación causal. Así, en el presente escrito se expondrán también las fórmulas que se consideran más apropiadas para dar solución a los problemas mencionados, encontrando en 
las reglas de proporcionalidad o probabilidad las construcciones con mayor solidez a la hora de afrontar las situaciones inciertas puestas de presente.

Finalmente, se evidenciará cómo la tesitura propuesta muestra sus mayores bondades en ámbitos en que la causalidad es sumamente controversial, como sucede, por ejemplo, en la esfera de la responsabilidad ambiental. Ciertamente, uno de los escenarios en donde se torna más dificultosa la determinación de la relación causa-efecto es el que tiene que ver con los daños irrogados al ambiente, comoquiera que allí son más que usuales las hipótesis de causalidad incierta, concurrencia de agentes y sobredeterminación. Por todo ello, se ha decidido aterrizar la propuesta planteada en el campo específico de la responsabilidad civil ambiental, que es uno de aquellos en donde esta puede reflejar sus mayores aciertos.

En cualquier caso, no sobra mencionar que no solo en el último acápite se aplica la cuestión al tema de la responsabilidad ambiental. En general, todas las reflexiones que se proponen a lo largo del escrito son especialmente aplicables a este particular escenario, comoquiera que en él se hacen patentes muchos de los grandes problemas de la causalidad contemporánea. En efecto, son de sobra conocidos, en la esfera ambiental, los problemas derivados de la concurrencia de contaminadores, de daños en masa, de daños anónimos, de contribuciones causales, entre otros; así las cosas, los problemas propios de la relación de la causalidad se hacen especialmente patentes en la esfera ambiental, en donde la incertidumbre es cuestión de todos los días. De ahí entonces que este estudio, en su integridad, tenga relevancia al análisis del problema causal en el escenario de la responsabilidad civil ambiental, en los términos ya señalados.

Con esto se intenta exponer un sistema de adecuación casual en materia de responsabilidad civil que ofrezca el remedio más idóneo a las dificultades que hoy en día se presentan en esta materia, abriendo el debate, a partir de la crítica positiva, a la reformulación de las teorías actualmente empleadas.

\subsection{El problema general de la relación de causalidad y su solución}

\subsubsection{Causalidad en materia de responsabilidad civil. Una aproximación a las diferentes teorías \\ El nexo de causalidad en materia de derecho de daños toma su definición de otras ciencias. En efecto, diferentes planteamientos filosóficos, físicos y}


científicos proporcionan las bases para la construcción del concepto causal en la esfera jurídica. ${ }^{5} \mathrm{El}$ primer autor reconocido en adelantar un estudio sistemático sobre esta materia fue Aristóteles; el filósofo griego propuso una tipología causal formada por cuatro tipos de causas, a las cuales denominó causa formal, causa material, causa eficiente y causa final. ${ }^{6}$ De todas estas categorías, la causa eficiente es la que nos permite identificar la existencia de una relación causa-efecto entre la actuación de un sujeto y un daño, pues es esta la que predica que "es causa lo que da comienzo al cambio o a la quietud, por ejemplo, el autor de una decisión es la causa de ella, el padre es causa del hijo y, en general, lo que produce el cambio es causa de éste" (Abbagnano, 1992, pp. 136-138). Esta concepción ha permeado al derecho. Así, por ejemplo, el profesor Luis Díez-Picazo, al comentar la definición de causa presentada en la Enciclopedia de Diderot y D'Alembert, expresa: "[C] ausa es todo aquello en virtud de cuya eficacia una cosa es; y efecto todo aquello que es en virtud de la eficacia de una causa" (Díez-Picazo, 2007, p.359), ${ }^{7}$ de donde entonces se colige que la consabida causalidad no es más que

${ }^{5} \mathrm{Al}$ respecto se ha dicho que "mientras la causalidad genera una serie de preguntas interesantes en la filosofía - p. ej.la crítica de David Hume (1711-1776) hacia el entendimiento convencional de la necesidad causal一, su discusión dentro de la filosofía del derecho se relaciona normalmente con la manera en que dicho concepto ha sido reformulado por la doctrina jurídica, a fin de reflejar ideas e intuiciones relativas a la responsabilidad moral y a las políticas públicas. En el derecho, al igual que en la filosofía moral, el tema de la 'causalidad' está estrechamente ligado con la atribución de responsabilidad o culpa derivada de un incidente o suceso, aunque en un sentido más amplio o empírico de 'causalidad'el incidente o suceso haya sido el producto de un número de acciones y circunstancias más extensas, y quizá infinitas" (Bix, 2009, p. 74). Así mismo, el profesor Díez-Picazo reconoce: "Aunque la utilización del concepto de causa por los juristas haya tenido su origen en consideraciones de orden filosófico, al trasladarlo después a un lenguaje usual, es muy probable que la apreciación causal en materia jurídica se comenzara haciendo de una forma artesanal, de acuerdo con las experiencias de que se disponía" (Díez-Picazo, 2007, p. 359).

${ }^{6}$ Sobre este punto, Goldenberg hace el siguiente aporte: "Es, sin embargo, con Aristóteles que puede situarse el inicio del llamada 'causalismo científico'. El Estagirita requiere el concurso de cuatro causas para la producción de cualquier resultado. Todo efecto, de acuerdo con su pensamiento, ha de ser producido por algo o por alguien (causa eficiente), para algo (causa final), de algo (causa material) y con introducción de algo (causa formal). Se distinguen, de este modo, cuatro géneros de causa: efficiens, finalis, materialis y formalis. La causa material y la formal con causas del ser; la eficiente y la final, causas del devenir" (Goldenberg, 1984, p. 5). Cfr. Engle (2009, p. 3).

${ }^{7}$ Nicola Abbagnano, en su diccionario de filosofía, comenta sobre la causalidad que "en su significado más general, la relación entre dos cosas, en virtud de la cual la segunda es unívocamente previsible a partir de la primera. Históricamente esta noción ha adquirido dos formas fundamentales: 1) la forma de una relación racional, por la cual la causa es la razón de su efecto que, por lo tanto, es deducible de ella. Esta concepción describe a menudo la acción de la causa como una fuerza que genera o produce necesariamente el efecto;2) la forma de una relación empírica o temporal, por la cual el efecto no es deducible de la causa, pero es previsible 
"el enlace material entre un hecho antecedente y un resultado (daño), conocido en la doctrina como 'imputabilidad o atribuibilidad objetiva', 'imputatio facti o vínculo material" (Goldenberg, 1984, p. 2), que, por lo demás, en su condición de elemento axiológico de la responsabilidad civil, tiene la función de dar respuesta a dos preguntas estructurales: ¿quién debe responder? y ¿hasta dónde debe responder?8

Ya lo señalaba Díez-Picazo, para quien:

\begin{abstract}
[E]1 concepto de causa y el de causalidad se utilizan en materia de responsabilidad civil, para tratar, básicamente, de dar respuesta a dos tipos de problemas: el primero es encontrar alguna razón por la cual el daño puede ligarse con una determinada persona, de manera que se pongan a cargo de ésta, haciéndola responsable, las consecuencias indemnizatorias, para lo cual se utiliza el concepto de causa en el
\end{abstract}

a partir de ella, por la constancia y uniformidad de la relación de sucesión. Esta concepción elimina de la relación causal la idea de fuerza. A ambas formas les es común la noción de la previsibilidad unívoca, esto es, infalible, del efecto, a partir de la causa y por lo tanto de la necesidad de la relación causal"(1987, p. 152).

${ }^{8}$ Sobre este punto, De Cupis expone: "No menor importancia reviste el establecer la magnitud, o sea, la dimensión o montante, el quantum del daño al que el ordenamiento jurídico atribuye valor de hecho jurídico, uniéndole una reacción propia. Establecida la transmisión de la carga del daño de un sujeto a otro, importa precisar, además, cuánto daño deba experimentar tal transmutación y cuánto daño deba ser eventualmente soportado por el que lo ha sufrido. La determinación del quantum respondeatur tiene, precisamente, tanta importancia como la del determinar al an respondeatur, porque, de poco serviría tener derecho al resarcimiento si fuese mínima la entidad del daño a resarcir. En consecuencia, importa enormemente precisar los límites cuantitativos dentro de los que el daño asume sentido jurídico [...] E1 contenido jurídico del daño, está ante todo, en función de la relación de causalidad entre el hecho productor del daño y el daño, es decir, que para fijar el montante del daño que debe reprimirse jurídicamente, se requiere, en primer lugar, establecer los límites dentro de los que el daño pueda considerarse causado por un hecho humano provisto de los atributos exigidos por la ley con fines de responsabilidad" (De Cupis, 1970, pp. 245-246). Sobre el particular, Prevot comenta: "La causalidad cumple en el derecho de la responsabilidad civil dos funciones: 1) una relativa a la imputación del hecho dañoso a su autor $\mathrm{o}$, si se prefiere, tendiente a la individualización del responsable, denominada por buena parte de la doctrina autoral italiana como 'causalidad material'; y 2) otra, consistente en determinar el contenido de la obligación resarcitoria, conocida como 'causalidad jurídica'. Una cosa es, entonces, emplear la causalidad a los fines de imputar el evento lesivo a un sujeto (causalidad como requisito autónomo de la responsabilidad), y otra muy distinta es utilizar la causalidad para determinar la medida de la reparación (causalidad como complemento). En el primer caso, se responde al interrogante ¿quién causó el daño? (etapa del an respondeatur). Mientras que en el segundo, se responde a la pregunta ¿cuánto debe pagar el responsable? (etapa del quantum respondeatur). Esta doble función que cumple la causalidad en el ámbito de la responsabilidad civil, junto a las diversas formas que forzosamente adquiere la misma, según el ámbito of fattispecie en que opere, imposibilitan todo intento de reconstrucción unitaria" (2010, p. 146). 
artículo 1902 cc [análogo del artículo 2341 de la codificación colombiana] al imponer el deber de indemnizar a 'el que causa daño a otro'; en segundo lugar, se trata de relacionar, a la inversa de lo que hacíamos anteriormente, al daño con la persona, pues el precepto, remarcando el uso de la palabra causa, dice que se indemniza 'el daño causado' $(2007$, p. 235$){ }^{9}$

En similar sentido, Ramón Daniel Pizarro afirma que la causalidad brinda "los parámetros objetivos indispensables para calibrar la extensión del resarcimiento, mediante un régimen predeterminado de imputación de consecuencias. A través de ella se determina hasta dónde el sistema vigente quiere que el autor material responda por sus actos evitándose la elongación excesiva del perjuicio y el enriquecimiento consiguiente del damnificado" (Pizarro, 2006, p. 89). ${ }^{10}$

De esta forma, se tiene que la causalidad permite al demandante determinar contra quién debe dirigir su pretensión indemnizatoria y cuáles son

\footnotetext{
${ }^{9}$ En igual sentido, señala López Mesa: "Para que una persona pueda ser tenida como civilmente responsable por un acto ilícito dañoso, resulta imprescindible que el daño pueda ser objetivamente atribuido a la acción u omisión de un hombre o al hecho de una cosa —imputatio facti o relación de causalidad-. En palabras del profesor Brun, 'responsabilidad civil y causalidad son consustanciales" (Trigo Represas y López Mesa, 2011, p. 360). Para Le Tourneau, "racionalmente la responsabilidad civil supone un nexo de causa a efecto entre el perjuicio y el hecho dañino. Este último debe haber sido causa generadora del daño, así como la cosa debe haber desempeñado un papel activo en la producción del daño. Los términos de los artículos 1382 y siguientes justifican este principio: todos exigen que el hecho, la cosa, el animal o el edificio causen el daño. Solo el perjuicio directo podrá ser reparado, porque solo él está ligado por ese nexo de causa a efecto al acto imputado al responsable, el hecho generador" (2010, p. 78). En el ámbito colombiano, Pérez Vives señala: "Para que surja la obligación de reparar un daño es preciso que entre éste y la culpa exista un vínculo que permita afirmar que el primero es efecto de la segunda. En otras palabras, que la culpa haya causado el perjuicio" (1992, p. 327). De igual manera, el profesor Arturo Solarte indica: "Para que se pueda reclamar la reparación del daño antijurídico debe existir una relación de causalidad entre el hecho que lo ha provocado y la conducta de quien se dice fue su autor, sea que ésta haya consistido en una acción o, simplemente, en una omisión" (2004, p. 711).

${ }^{10}$ En otro de sus escritos, dice el mismo autor que "dentro del ámbito de la responsabilidad civil, la relación de causalidad asume una doble función, de singular importancia: a) permite determinar, con rigor científico, cuándo un resultado dañoso es material u objetivamente atribuible a la acción del sujeto determinado; b) brinda, al mismo tiempo, los parámetros objetivos indispensables para calibrar la extensión del resarcimiento, mediante un régimen predeterminado de imputación de consecuencias. Éste es uno de los grandes pilares sobre los que se edifica el moderno derecho de daños, que debe orientar sus esfuerzos hacia una justa e integral reparación de todo detrimento injustamente causado" (Pizarro, 2000, pp. 255-256).
} 
los daños que tiene derecho a que le sean reparados por ese agente dañador. Así mismo, la comprobación de la existencia de un nexo de causal entre la actuación de un sujeto y un menoscabo injustificado en los derechos de una persona permite al juzgador, a la hora de un juicio de responsabilidad civil, imponer la condena única y exclusivamente al causante del daño y obligarlo a resarcir solamente los perjuicios que ocasionó con su conducta.

Finalmente, desde la perspectiva del acusado de haber irrogado un daño, la causalidad le permite ejercer su defensa para que ante la ausencia de esta fracase la pretensión indemnizatoria dirigida en su contra. ${ }^{11}$ De allí se colige también que la causa supone un elemento moralizador: permite hacer patente una exigencia de justicia correctiva en la responsabilidad civil, comoquiera que impone la obligación de indemnizar solamente a quien ha dado lugar a la interacción injusta, del modo que lo sugieren las concepciones contemporáneas de esta forma de justicia. Puesto en otros términos, la causalidad evita que el débito indemnizatorio se disperse en cabeza de cualquier sujeto y lo concentra en cabeza del agente dañador, con lo que cristaliza una exigencia de justicia —y, más específicamente, de justicia correctiva— en la responsabilidad.

El inconveniente, con todo, es que, a la utilidad e importancia práctica de la causalidad, se suma una dificultad ostensible en su análisis y determinación.

\footnotetext{
${ }^{11} \mathrm{Al}$ respecto, el maestro Fernando Hinestrosa explica que "en presencia de un quebranto patrimonial o moral salta a la vista la necesidad de buscar su origen, indagar por el responsable. Si se trata de un daño que la propia víctima maliciosa o descuidadamente se ocasionó, mal podría ella achacarlo a persona distinta, o como se diría en lenguaje familiar, 'buscar el ahogado río arriba'. Si el perjuicio lo causó persona distinta del demando y por la que no está llamado él a responder, a ese tercero deberá acudir la víctima y no a quien nada tiene que ver en el asunto. Por último, si la ocurrencia provino de fuerzas naturales o sociales anónimas e irresistibles, la víctima habrá de padecer su mala suerte sin posibilidad de descargar su quebranto sobre persona determinada" (1961, p. 358). De esta forma, cuando existe una causa extraña, sea esta por la intervención de un tercero (hecho de un tercero), por la propia aportación de la víctima en la producción del daño (hecho de la víctima) o por una causa ajena que revista las características del caso fortuito o fuerza mayor, que dependiendo de su magnitud pueden aminorar o suprimir el vínculo causal de la conducta del agente señalado como dañador con el perjuicio. Para el caso colombiano,Juan Pablo Cárdenas Mejía expone: "ElCódigo Civil colombiano no consagra expresamente la causa extraña como factor de exoneración de responsabilidad, sino que se refiere a la fuerza mayor y al caso fortuito. Sin embargo, la jurisprudencia y doctrina se refieren a la causa extraña como eximente de responsabilidad. Históricamente la distinción entre causa extraña y fuerza mayor surge de la redacción del Código Civil francés que hace referencia a dichos conceptos. Aunque la noción de causa extraña se basa en la redacción de dicho código, ha sido recogida por nuestra doctrina en la medida en que agrupa aquellos elementos que exoneran de responsabilidad y que son ajenos al deudor o a la persona a la que se le pretende imputar la responsabilidad. Tradicionalmente se han señalado como casos de causa extraña la fuerza mayor o el caso fortuito, el hecho de un tercero o el hecho de la víctima" (2010, p. 349). Sobre el mismo tema, se pueden consultar: Pizarro (2000, pp. 255 y ss.) y Medina Alcoz (2003).
} 
Ciertamente, como se ha expuesto a lo largo del texto, por sencillo que pareciera, en principio, adelantar el análisis de causalidad, lo cierto es que las ciencias jurídicas se encuentran aún lejos de encontrar una teoría que responda satisfactoriamente a tales interrogantes. ${ }^{12}$ Como lo resalta el profesor Jorge Santos Ballesteros, "a pesar de su presencia ineludible, sin embargo, y no obstante constituir esa relación el enlace entre el hecho causante del ilícito y el detrimento de la reparación, no siempre su configuración jurídica ha obedecido a criterios uniformes o patrones definidos, al contrario de lo sucedido con los otros dos factores integrantes de la responsabilidad civil, es decir, la culpa y el daño"(2013, p. 376). Para dar una idea del laberinto que representa desentrañar el nexo de causalidad en materia de responsabilidad civil, resalta ilustrativo un difundido ejemplo doctrinal. Supóngase la siguiente situación:

Leo en el diario $A B C$ : "Un perro cae al vacío y provoca varias muertes consecutivas. Una cadena de sucesos trágicos se sucedió en el barrio bonaerense de Caballito a partir del momento en que un perro cayó accidentalmente desde un decimotercer piso. 'Cachi', que así se llamaba el animal, fue a golpear en la cabeza de Marta Fortunata, de setenta y cinco años, que caminaba despreocupada por el lugar. Como consecuencia del impacto, la anciana murió de forma instantánea. Seguidamente, una rueda de curiosos se comenzó a formar en torno al cadáver. El corro desbordó pronto la acera y comenzó a ganar parte a la calzada, donde el tráfico se desarrollaba a gran velocidad. En ese

\footnotetext{
${ }^{12}$ Con claridad expone sobre esta problemática Tamayo Jaramillo, quien afirma: "La doctrina pareciera resignarse ante la imposibilidad de dilucidar con claridad el problema del nexo causal y encontrar una teoría que lo solucione satisfactoriamente. Al respecto, Geneviève Viney expresa: 'Numerosos juristas de todos los países han puesto seriamente en duda la utilidad de las tentativas de solución científica del nexo de causalidad'. En Francia, Ripert, por ejemplo, ha tomado posición muy clara en favor de una actitud puramente pragmática al respecto, y en ese sentido expresa: 'La jurisprudencia haría bien si rechaza el entregarse al análisis de causalidad porque ésta ha suscitado brillantes estudios doctrinales que no han aportado ninguna solución a este problema general que es tal vez insoluble'. Y los señores Mazeaud, de su lado, después de haber recordado que la causalidad debe ser cierta, lo que implica, dicen ellos, que el daño es la consecuencia necesaria del hecho percibido, confiesan que es difícil dar más precisión sobre la noción de daño indirecto y se pliegan a la opinión de Demogue para quien 'se trata de una cuestión de buen sentido más que de ciencia... que ha agotado las paciencias más probas'. Estos autores se limitan a dar ejemplos sin pretender alcanzar una noción general. Boris Starck va más lejos aún, puesto que afirma sobre este punto que 'todo ensayo de razonamiento científico se vuelve ineficaz', lo que parece igualmente ser la opinión de Esmein” (2007, p. 380).
} 
momento, un autobús alcanzó de lleno a Edith Solá, de cuarenta y seis años, quien murió en el lugar después de haber sido arrastrada varios metros por el vehículo. Cuando el estupor de los presentes ante este trágico suceso no había desaparecido, frente al escenario de los hechos, un hombre que no fue identificado sufrió un ataque cardíaco y murió minutos después, en el interior de la ambulancia que lo trasladaba a un hospital"(Yzquierdo, 2001, p. 1987).

Ante esta cadena de eventos infortunados aflora la duda sobre la causa que los ha generado y quién será el llamado a responder. Dependiendo de la teoría jurídica de determinación causal que se adopte, ya sea la teoría de la equivalencia de las condiciones, la teoría de la causa próxima, la teoría de la causa eficiente, la teoría de la causa adecuada, o se opte por la teoría de la imputación objetiva, la decisión sobre quién deberá soportar la reparación del perjuicio podrá variar, como se pasa a ver.

Para determinar la causa de un daño, la teoría de la equivalencia de las condiciones utiliza un juicio contrafáctico, en el cual se parte de la supresión de los eventos considerados como posibles causas del perjuicio, para evaluar si a pesar de la falta de alguno de estos el daño subsiste. Si la respuesta al realizar dicha operación es negativa (la consecuencia no desaparece a pesar de la omisión de la posible causa), se descarta dicha posible causa; por el contrario, si la respuesta es positiva (la consecuencia desaparece por la omisión de la posible causa), se tiene a este por causa del daño y, además, se le tiene en iguales condiciones que todos los demás que cumplan con el test, considerándolas a todas conditio sine qua non del perjuicio irrogado, por cuanto "faltando cualquiera de ellos, el daño no se habría producido" (Le Tourneau, 2010, p. 79). ${ }^{13}$ Es, en esencia, la estructura del juicio contrafáctico típico.

Para mayor claridad, se examina el caso expuesto anteriormente a luz de la teoría presentada, a fin de ejemplificar lo que sería el resultado de un juicio de causalidad bajo esta concepción. Ante la muerte de la señora, es evidente que, si se suprime la caída del perro desde lo alto, se arriba a la conclusión de

${ }^{13}$ Sobre la teoría de la equivalencia de las condiciones, Díez-Picazo explica: "Cuando un resultado aparece tras un conjunto de condiciones, el método experimental exige suprimir mental o empíricamente cada una de ellas. En este sentido, causa es la condición sine qua non del daño, es decir, aquel de los elementos o las condiciones que, si hubieran faltado, el resultado dañoso no se hubiera producido. Si se quita la causa, desaparece la consecuencia (sublata causa tollitur efectus)" (2007, p. 360). 
que esta es conditio sine qua non de esta eventualidad, comoquiera que, a falta de perro, no habría resultado dañoso.

Pero, de otro lado, si se suprime el hecho de que quien habita en dicho apartamento del decimotercer piso tuviera dicha mascota, lo cierto es que el resultado dañoso tampoco habría ocurrido, lo que haría que el hecho de vivir en ese piso con una mascota se erija también en causa del daño. Más aún, si se realiza el juicio contrafáctico en relación con la existencia de un edificio de dicha altura, la conclusión es que en ausencia de este la muerte no hubiera tenido lugar; el constructor sería entonces también detonante causal del hecho. Se tiene entonces, a partir de la teoría de la equivalencia de las condiciones, que el nexo causal se extiende ad infinitum, pues se equiparan las condiciones para la producción del hecho dañoso a las causas de este, ${ }^{14}$ dando lugar a respuestas inequitativas, ya que expande la órbita de responsabilidad a agentes que, por la lejanía con el hecho dañoso, carecen del vínculo necesario con el daño como para que sean condenados a repararlo, tal como sería el caso del constructor del edificio. ${ }^{15}$

En este punto se asientan las principales críticas que se han esgrimido en contra de esta teoría. Jurídicamente resulta inaceptable expandir ad nauseam la relación causal entre un hecho y un resultado. ${ }^{16}$ Si bien la teoría de la

\footnotetext{
${ }^{14}$ Sobre la diferencia que debe existir entre condiciones y causas de un daño, que no se logra al aplicar la teoría de la equivalencia de las condiciones, Pizarro manifiesta: "La condición es un mero antecedente del resultado que produce. Ordinariamente un efecto es producido por múltiples condiciones, que en conjunto lo provocan. El derecho, como regla general, no atribuye autoría material del daño, ni responsabiliza a un sujeto por el mero hecho de haber puesto una condición, aunque esta pueda ser necesaria para su producción, ya que en caso de no haberse producido, el efecto no se habría desencadenado. Es preciso, para ello, que la condición asuma especial entidad, por ser adecuada para producir ese resultado, en cuyo caso se eleva a la categoría de causa jurídica, generadora del detrimento. Así concebida la cuestión, puede afirmarse que 'si bien la causa es siempre una condición de daño, no toda condición es causa'. Dentro de las muchas condiciones que pueden contribuir a un resultado, encontramos a la ocasión, que favorece o torna viable la actuación de la verdadera causa del daño, pues permite, facilita o potencia su aptitud causal. En principio no se responde por el mero hecho de haber facilitado o provocado la ocasionalidad del daño. Quien invita a un amigo a practicar golf, no responde si en ocasión del juego, éste es lesionado por la pelota lanzada al jugador, o es agredido con motivo de una discusión con otro competidor" (2006,p. 91).

${ }^{15}$ Adicionalmente, el profesor Suescún Melo pone de presente que "se le reprocha su falta de elasticidad, pues exige, en caso de concurrencia de culpas con la víctima, dividir por partes iguales la indemnización, pues recuérdese que esta doctrina considera que todas las causas concurren del mismo modo a la producción del daño, lo que puede estar en oposición con la equidad”(2003, p. 150).

${ }^{16}$ Con todo, hay quienes también critican esta teoría por dejar impune al autor de ciertos daños. Así lo hace Díez-Picazo, para quien "la fórmula de la condición snq [sine qua non] peca también, sigue diciendo Antunes Valera, además de por exceso, por defecto, ya que no comprende dentro del nexo de
} 
equivalencia de las condiciones permite materialmente determinar un vínculo causa-efecto, lo cierto es que lo hace desde un punto de vista material o natural; desde el derecho de daños, no es equitativo el criterio que ella propone para imputar a alguien una condena a reparar los perjuicios sufridos por otra persona. ${ }^{17} \mathrm{Al}$ respecto, Philippe Le Tourneau hace la siguiente reflexión:

Si en otras épocas esta teoría podría permitir una reparación equitati-
va de los daños, en una economía esencialmente agrícola y artesanal,
ya eso no ocurre hoy en día. El progreso técnico, que permite manejar
las fuerzas naturales considerables, el desarrollo del maquinismo, las
interacciones más frecuentes de las actividades humanas, a veces pro-
vocan consecuencias en las que es imposible determinar la parte de
cada uno de los intervinientes y cuya amplitud está sin común medida
con el papel propio de cada uno de ellos. En fin, para la determinación
del nexo de causalidad entre el hecho daniño y sus consecuencias me-
diatas, necesarias para calificarlas directas, la equivalencia de las con-
diciones conduce a considerar que permanecen directos y reparables
los daños demasiado alejados del hecho generador y, para decirlo de

causalidad, ciertos daños que sería injusto no pone a cargo del autor de un hecho, como ocurre en la hipótesis que ha sido denominada de causalidad acumulativa o alternativa o en los daños causados por miembros indeterminados de un grupo que efectúa disparos o lanza cócteles molotov, sin que ninguno de ellos, aisladamente considerado, se pueda decir que sin él no hubiera ocurrido el daño sufrido por la víctima, no es causante del daño de manera que habría que entender que no debe ser considerado responsable del daño en el sentido de la sqn del daño verificado. Y, al revés, si, como ocurre en el parágrafo 830 del вGв, se considera que hay autoría múltiple, el daño se está imputando a persona o personas que no lo han causado" $(2007$, p. 361).

${ }^{17}$ En palabras de De Cupis, "la objeción que se ha formulado a la teoría de la condicio sine qua non es que, mediante ella, el concepto de causa y, por ende, la responsabilidad, se extienden excesivamente. Indudablemente es necesario que el hecho humano sea condición del daño, pero se desplaza el problema a determinar un quid posterior que establezca los límites razonables de la responsabilidad" (1970, p. 256). Con igual criterio señala Atilio Aníbal Alterini, "sutil y vigorosa es la ironía que dedicó Binding a esta teoría, luego de afirmar que según ella todo el mundo es culpable de todo: correspondería castigar como coautor de adulterio no sólo al varón que yace con la mujer casada con otro hombre, sino también al carpintero que hizo la cama" (1992, p. 144). El profesor Santos Ballesteros trae a colación el comentario que sobre el particular hace Pierano, para quien, "aplicada rigurosamente la teoría de la equivalencia de condiciones, tiende a ensanchar en forma exagerada el concepto de causa hasta el punto de hacer de esta noción una idea reñida con el sentido común y con el concepto vulgar de justicia. Suponiendo que en un caso dado concurrieran a producir cierto evento una condición y un caso fortuito, habría que imputar el caso fortuito a quien ha puesto una sola de las condiciones, lo cual es contrario a todo principio ético-jurídico y también el bueno sentido" (2013, p. 393). 
una vez, cuyo nexo con éste es puramente hipotético. El problema mayor de la teoría explota aquí: ésta no permite fijar cómodamente un límite a la extensión de la responsabilidad (2010, p. 81).

En suma, la respuesta que ofrece la equivalencia de las condiciones es una respuesta insuficiente para el derecho. Ciertamente, el criterio de esta teoría, cuando es empleado como único test para determinar la relación de causalidad, no ofrece una respuesta satisfactoria, comoquiera que supone un regreso al infinito en el que la causa de la causa es la causa del mal causado. Esto no quiere decir, en cualquier caso, que sea un criterio erróneo. Para dilucidar la causa desde una perspectiva física o naturalística, la equivalencia de las condiciones o test sine qua non reviste gran utilidad, dado que ofrece una verificación muy certera, al menos en el plano de la acción - comoquiera que en el caso de la omisión ofrece dificultades-. Tal vez de lo que requiere es de un complemento jurídico que permita delimitar el regreso al infinito, como se expondrá en un segmento ulterior.

Ahora bien, lo cierto es que, ante la falta de una respuesta satisfactoria desde la teoría de la equivalencia de las condiciones, se han postulado diversas construcciones doctrinarias que intentan presentar diferentes criterios para solucionar la vis expansiva que la conditio sine qua non inconvenientemente proporciona al adelantar el juicio de causalidad en materia de responsabilidad civil.

Así ha surgido, por ejemplo, la teoría de la causa próxima, que es una construcción teórica que, aunque cronológicamente anterior, presenta un criterio que permite escoger, entre las condiciones que producen un daño, a una de ellas como única causa de este. Para la causa próxima únicamente existe nexo de causalidad, a los ojos de la responsabilidad civil, entre el daño y el último hecho que lo precedió. ${ }^{18} \mathrm{El}$ juicio que se realiza cuando se escoge esta teoría para desentrañar la relación de causalidad consiste en seleccionar, entre las múltiples condiciones que dieron lugar al perjuicio, la que cronológicamente lo antecedió —esto es, la inmediatamente anterior al resultado dañoso-,

\footnotetext{
${ }^{18}$ Se ha dicho que, de acuerdo con esta teoría, de origen angloamericano, "la auténtica causa sería la proximate cause y al elegir a esta habría que rechazar todas las que fueran too remote cause. En esta doctrina si existieran condiciones sucesivas que todas ellas son causa de los daños, sólo debería utilizarse la causa más próxima” (Navarro, 2013, p. 191). Sobre la aplicación concreta de esta teoría a un caso concreto, se puede ver: Palsgraf v. Long Island Railroad Co.
} 
evitando de esta manera entrar a hacer juicios ulteriores que den resultados inciertos y que impliquen en términos de Bacon, su autor, una tarea infinita. ${ }^{19}$ Asevera Santos Ballesteros que, "defendida especialmente en Inglaterra, la teoría de la causa inmediata parte de adoptar en la cadena o eslabón de acontecimientos que se entrelazan en la producción de un fenómeno un criterio netamente temporal, para hacer resaltar el que esté más cercano o próximo al resultado" (2013, p. 394).

La solución que a la luz de esta teoría se daría al caso propuesto precedentemente resulta relativamente sencilla: la causa de la muerte de la señora es el golpe que le propinó el perro al caer sobre su humanidad. A eso se reduce el estudio de la causalidad cuando de causa próxima se trata.

Sin embargo, y aunque es evidente lo efectiva que resulta esta teoría para individualizar la causa de un daño, lo cierto es que no se encuentra libre de reparos. Mariano Yzquierdo manifiesta que, "a la dificultad de establecer cuál ha sido la condición última en un suceso, se añade que no siempre el antecedente temporal más próximo en la cadena causal es el determinante. El concepto de inmediatez ha de tener, por lo tanto, un sentido más lógico que cronológico" (2011, pp. 416-417). ${ }^{20}$

Por estas razones, que evidencian lo inequitativo que resulta en muchos casos la aplicación de esta construcción teórica, es que no logró asentarse ni alcanzar mayor influencia en la doctrina, ${ }^{21}$ dando paso a nuevas teorías jurídicas que han logrado mayor aceptación, impregnando la jurisprudencia de diversas latitudes.

${ }^{19}$ Sobre la teoría de la causa próxima, afirma el profesor Gerardo Ortiz Gómez que "fue expuesta por Francis Bacon en su obra Maxims oflaw, publicada en el siglo xvi; es decir, fue planteada con mucha anterioridad a la teoría de la equivalencia de condiciones. La máxima elaborada por Bacon señala: 'Sería para el derecho una tarea infinita juzgar las causas de las causas y las acciones de las acciones de unas sobre las otras: por eso se contenta con la causa inmediata y juzga los actos desde ese punto de vista sin remontarse a un grado superior'; así las cosas solo el hecho más próximo en tiempo al daño es el causante de éste" (2010, p. 322).

${ }^{20}$ Sobre las objeciones formuladas a esta teoría, se puede ver: Trigo Represas y López Mesa (2011, pp. 416-417).

${ }^{21}$ Señala Santos Ballesteros que "la tesis de la causa inmediata o causa próxima no es admitida por la generalidad de la doctrina, por la injusticia evidente que encierra su formulación, dado que de aplicarse, daría lugar a atribuir consecuencias dañosas a actos que en sí mismos no tiene la aptitud para producir un resultado, o no atribuirlas a los que sí la tienen, al faltar la correspondencia necesaria que debe existir entre uno y otro de los extremos de la responsabilidad, pues la disposición cronológica no se corresponde siempre con la causal o lógica que debe presidir este análisis" (2013, p. 396). 
Es el caso, por ejemplo, de la teoría de la causa eficiente, que, como lo dice Jorge Suescún Melo, "ha tenido el favor de un sector importante de la doctrina y de la jurisprudencia nacionales recientes" (2003, p. 161). Para esta formulación doctrinaria "no interesa ya el acontecimiento que ha precedido inmediatamente al daño, sino que hay que establecer su condición causal según el grado de eficiencia en el resultado (causa efficiens), en oposición al principio de indiferencia de las condiciones sustentado por la teoría de la conditio sine qua non" (Goldenberg, 1984, p. 27).

La causa eficiente prescinde entonces de factores cronológicos; no resulta relevante para este juicio de causalidad lo cercanos o alejados en el tiempo que se encuentren el hecho y el daño para el establecimiento del nexo causal.

Ella eleva a la categoría de causa en sí, a la condición más activa en la producción del resultado. Trata de encontrar, dentro del amplio concurso de condiciones que intervienen en la generación de un resultado, una que, en razón de su intrínseco poder de producción del fenómeno que se aprecia como tal resultado, recibe la calificación preponderante de ser considerada su causa, lo que importa distinguir, tanto cualitativa como cuantitativamente, una condición de las demás (Trigo Represas y López Mesa, 2011, p. 418).

De ahí que, al estudiar la relación de causalidad, se deba diferenciar entre la causa, la condición y la ocasión. La primera, es decir, la causa, es aquella que ha contribuido de manera prevalente a la producción del daño. Por otro lado, la condición es aquella que gesta el entorno necesario para que la causa produzca el resultado, el cual está intrínsecamente en capacidad de producir. Por último, la ocasión favorece la producción del daño siendo prescindible para su producción.22

Así, concretando la referencia teórica en el ejemplo que se ha venido trabajando, se puede decir que la causa eficiente para la muerte de la señora es el golpe que el perro le propinó al caer. Que la caída fuese de un decimotercer

\footnotetext{
${ }^{22}$ Así lo asevera Suescún Melo, para quien "la causa eficiente es la causa propiamente dicha, es decir, responde a la pregunta: ¿por quién fue hecho el daño? Y puede definirse como aquello que por su acción produce alguna consecuencia. La condición, en cambio, no produce el efecto sino simplemente permite a la causa eficiente producirlo; descarta, si se quiere, un obstáculo permitiendo así la acción de la causa eficiente. La ocasión no hace más que favorecer el juego de la causa eficiente y en ningún modo es necesaria para la producción del daño" (2003, p. 162).
} 
piso es una condición de dicho daño, pues proporciona la altura necesaria para que el impacto tenga la magnitud suficiente para producir el efecto, pero por sí sola no tiene tal potencialidad. Como ocasión se puede catalogar el que la señora estuviere caminando para ir a algún lugar, actividad que propicia que se irrogue el daño aunque no sea necesaria para su realización.

Aunque el criterio proporcionado por la teoría en mención pareciera suficiente e idóneo para postularse como el juicio de causalidad que deben seguir los tribunales, lo cierto es que son múltiples las críticas que se le han hecho. Observa Isidoro Goldenberg que, "cuando se trata de establecer en la práctica la pauta que permita seleccionar entre las diversas condiciones de un resultado la más eficiente o la más preponderante, se advierte con nitidez la fragilidad de estas teorías. En efecto, la imposibilidad de escindir materialmente el resultado, de suyo indivisible, para atribuir a una condición per se un poder causal decisivo, hace caer dichas construcciones teóricas en un empirismo que las despoja de todo rigor científico"(2011, pp. 419-421).

Si bien esta teoría ha ejercido una fuerte influencia en la jurisprudencia colombiana, ${ }^{23}$ lo cierto es que no ha sido la tesis con más acogida. En realidad, ha sido la teoría de la causalidad adecuada la que mejor recepción ha mostrado tener en las cortes y en la doctrina. En tal medida, se hará un estudio más detenido sobre esta en el acápite siguiente, cerrándolo con las críticas que se le enrostran a esta teoría.

\subsubsection{La tesis de la causalidad adecuada}

La teoría de la causalidad adecuada es formulada "con la intención de limitar la responsabilidad en el campo de la causalidad, reduciendo los resultados excesivos a que conducía la teoría de la equivalencia de las condiciones" (Trigo Represas y López Mesa, 2011, p. 434). Como se mencionó, se trata de una concepción que goza de la mayor acogida tanto en la doctrina como en la jurisprudencia, lo que le ha permitido situarse en un lugar privilegiado a la hora de adelantar el juicio de causalidad en el derecho de daños. Por ello,

\footnotetext{
${ }^{23}$ Afirmaba Suescún Melo, en su obra publicada en 2004, que "la jurisprudencia nacional ha adoptado esta teoría donde emplea, incluso, la misma terminología. En efecto, en diversos fallos han subrayado la necesidad de distinguir, de entre los hechos que intervienen en la producción de un daño, aquellos que han sido 'causa generadora' y aquellos que solamente han sido la 'ocasión'. Por su parte, sentencias españolas han hablado de la causa eficiente y necesaria como la condición que tiene una 'consideración preminente' en la producción de hecho dañoso" (2003, p. 163).
} 
resulta de suma importancia analizar qué tan eficaz es en el cumplimiento de esta finalidad, para luego plantear las críticas que se han formulado en su contra y presentar una teoría que se considera más propicia para cumplir con el reto de desentrañar este elemento axiológico de la responsabilidad civil (Tamayo Jaramillo, 2007, p. 378; Trigo Represas y López Mesa, 2011, p. 433; Goldenberg, 1984, p. 30).

Pues bien, para entrar en materia, vale la pena recordar que debemos el origen de la teoría de la causalidad adecuada a Ludwig von Bar y a Johannes von Kries. Ciertamente, se ha señalado que se trata de una construcción que "fue elaborada en su versión original por Luis Von Bar en 1871, pero su elaboración final corresponde al fisiólogo J. Von Kries, [...]” (Ortiz Gómez, 2010, p. 324). De acuerdo con Díez-Picazo, quien sigue a Trimarchi en sus planteamientos,

Von Kries subrayó que la probabilidad, entendida como frecuencia de la relación entre dos clases de eventos, es un dato a tener en cuenta a la hora de establecer relaciones causales. Hay leyes naturales — dice Von Kries- que establecen una relación de necesaria secuencia entre dos tipos de eventos, pero otras se limitan a establecer una relación de frecuencia estadística. Von Kries ponía de manifiesto la importante función que los juicios de probabilidad tienen en la vida práctica, pues las consecuencias probables de una acción pueden servir de fundamento para valorar la acción como útil o como peligrosa. Es lógico que cuando el derecho tiene por objeto la prevención de acciones dañosas prohíba acciones que no sólo han sido condiciones sqn (sine qua non) de daños, sino que también aparecen como idóneas para producirlos en el sentido que aumentan en una medida importante la probabilidad de que se verifiquen. Además, la fuerza de la probabilidad es un juicio objetivo, que tiene en cuenta las uniformidades naturales y sociales, científicamente establecidas, en el momento en que el juicio se emite, de manera que éste se realiza sobre la base de una descripción generalizadora que comprenda las circunstancias del caso (2007, p. 364).

En el mismo orden de ideas, la Corte Suprema de Justicia de Colombia ha dicho sobre esta teoría que plantea, como postulado causal esencial, que 
[...] de todos los antecedentes y condiciones que confluyen a la producción de un resultado, tiene la categoría de causa aquél que de acuerdo con la experiencia (las reglas de la vida, el sentido común, la lógica de lo razonable) sea el más 'adecuado', el más idóneo para producir el resultado, atendidas por lo demás, las específicas circunstancias que rodearon la producción del daño y sin que se puedan menospreciar de un tajo aquellas circunstancias azarosas que pudieron decidir la producción del resultado, a pesar de que normalmente no hubieran sido adecuadas para generarlo [...]. Como se ve, la gran elasticidad del esquema conceptual anotado, permite en el investigador una conveniente amplitud de movimiento. Pero ese criterio de adecuación se lo acompañó de un elemento subjetivo que le valió por parte de un sector de la doctrina críticas a la teoría en su concepción clásica (entonces y ahora conocida como de la 'causalidad adecuada'), cual es el de la previsibilidad, ya objetiva o subjetivamente considerada. Mas, dejando de lado esas honduras, toda vez que su entronque con la culpa como elemento subjetivo es evidente, y éste es tema que no se toca en el recurso, el criterio que se expone y que la Corte acoge, da a entender que en la indagación que se haga —obviamente luego de ocurrido el daño [...] — debe realizarse una prognosis que dé cuenta de los varios antecedentes que hipotéticamente son causas, de modo que con la aplicación de las reglas de la experiencia y del sentido de razonabilidad a que se aludió, se excluyan aquellos antecedentes que solo coadyuvan al resultado pero que no son idóneos per se para producirlos, y se detecte aquél o aquellos que tienen esa aptitud. Sin embargo, cuando de asuntos técnicos se trata, no es el sentido común o las reglas de la vida los criterios que exclusivamente deben orientar la labor de búsqueda de la causa jurídica adecuada, dado que no proporcionan elementos de juicio en vista del conocimiento especial que se necesita, por lo que a no dudarlo cobra especial importancia la dilucidación técnica que brinden al proceso esos elementos propios de la ciencia — no conocidos por el común de las personas y de suyo sólo familiar en menor o mayor medida a aquellos que la practican - y que a fin de cuentas dan, con carácter general, las pautas que ha de tener en cuenta el juez para atribuir a un antecedente la categoría jurídica de causa. En otras palabras, un 
dictamen pericial, un documento técnico científico o un testimonio de la misma índole, entre otras pruebas, podrán ilustrar al juez sobre las reglas técnicas que la ciencia de que se trate tenga decantadas en relación con la causa probable o cierta de la producción del daño que se investiga (Díez-Picazo, 2007, p. 364).

Así las cosas, el análisis de la causalidad adecuada sugiere, para establecer el vínculo causal, que se debe determinar si un suceso era razonable y previsiblemente el más idóneo o adecuado para causar un resultado, teniendo en cuenta las máximas de la experiencia — si el asunto no requiere de un especial conocimiento técnico- o las reglas de la ciencia particular — si se trata de un asunto técnico- ${ }^{24} \mathrm{Si}$ la respuesta es positiva, esto es, si el suceso surge como idóneo para el resultado, a la luz de la experiencia y la razonabilidad, se tiene entonces que ese suceso es causa del resultado; contrario sensu, no existirá vínculo causal. A este razonamiento se le denomina prognosis póstuma. ${ }^{25}$

Nótese entonces cómo se trata de un juicio fundamentado, esencialmente, en los criterios de normalidad y probabilidad, por lo que la doctrina ha puntualizado que en la causalidad adecuada es preciso hacer, en realidad, un juicio de tipo probabilístico, que, por lo demás, se efectúa

\footnotetext{
${ }^{24}$ Sobre este juicio, López Mesa expone: “Se denomina prognosis póstumas (pronóstico objetivoretrospectivo - — mejor, 'juicio de adecuación causal' — al procedimiento consistente en determinar ex post facto la posibilidad de un resultado en función de las condiciones precedentes" (Trigo Represas \& López Mesa, 2011, p. 451). Tamayo Jaramillo, con cita de Dalcq, así lo expresa: "Esta teoría —la de la causalidad adecuada - considera también que para ser retenido como causa de un daño, un hecho debe ser la condición necesaria de dicho daño. Entendemos por ello la condición sine qua non, es decir aquella sin la cual el daño no se habría producido. Pero contrariamente a la afirmación de los partidarios de la equivalencia de las condiciones, la teoría de la causalidad adecuada rechaza esta equivalencia y declara que no todas las condiciones necesarias podrán ser retenidas como causas; no se retendrá más que aquellas que están unidas al daño por una relación de causalidad adecuado. Bajo esta condición suplementaria, los defensores de esta teoría entienden colocarse sobre el terreno psicológico para dar de la relación de causalidad una explicación práctica. Consideran que es necesario colocarse antes del evento para analizar el nexo de causalidad, lo que les conduce a no retener como causa sino los antecedentes de los cuales debía esperarse que produjeran el resultado que se realizó. Así, pues, esta teoría tiene por efecto eliminar entre los antecedentes aquellos que no han ejercido un papel en la producción del daño, más que por un encadenamiento que puede ser considerado excepcional" (2007, pp. 378-379).

${ }^{25}$ Sobre el uso de la estadística, como análisis de probabilidad, para acreditar la causalidad en materia de responsabilidad civil, se puede consultar: Barnes (2001, p. 1).
} 
... a posteriori, ex post facto y en abstracto, esto es prescindiendo de lo que efectivamente ha ocurrido en el caso concreto, y computando únicamente aquello que sucede, conforme al curso normal y ordinario de las cosas. Rumelin hacía referencia a este fenómeno como el 'pronóstico objetivo retrospectivo'. [...] Algunos han sostenido que el juez debería colocarse en la posición del autor del hecho, tomando en cuenta las circunstancias conocidas o cognoscibles por éste. La previsibilidad en tal caso no deja de ser valorada en forma abstracta, pero circunscripta al punto de vista del sujeto y a las condiciones en las que éste actuó.

Otros, en cambio, miran el hecho siempre objetivamente: el juez debe efectuar el juicio de previsibilidad en abstracto, tomando en cuenta todas las circunstancias que un hombre normal debería prever. Finalmente, una corriente ultra-objetiva estima necesario que el juez considere todas las circunstancias eximentes, incluso aquellas que no hubieren podido ser conocidas por el agente (Pizarro, 2006, p. 99).

El resultado puede entonces variar de acuerdo con la posición que se adopte, pues, al involucrar o prescindir de uno o más hechos, la previsibilidad y la probabilidad pueden llegar a variar drásticamente.

De esta forma el juicio de causalidad dependerá en un alto grado de la capacidad del juzgador de formar un panorama lo más completo posible, quedando en todo caso una porción muy amplia a su arbitrio. ${ }^{26}$ Por tal razón se ha dicho que "esta última teoría pierde rigor científico cuando percibimos las diferencias abismales que puede haber entre un juez y otro en relación con el criterio de adecuación, ya que lo que para un juez puede ser causa adecuada de un daño, para otro puede no serlo, sin que ninguno de los dos tenga argumentos científicos que justifiquen su punto de vista" (Tamayo Jaramillo, 2007 , p. 380).

\footnotetext{
${ }^{26}$ Para De Cupis, "no cabe duda de que al acoger el criterio de la regularidad causal se atribuye amplia importancia a la apreciación discrecional del juez, del que depende establecer si el daño ha sido o no un efecto regular del hecho humano. Pero en materia de relación causal, la apreciación discrecional del juez adquiere, necesariamente, una considerable importancia; $y$, por último, entre los varios criterios propuestos para mitigar la dureza de la teoría de la conditio sine que non, no hay duda de que la regularidad ha gozado de un mayor favor en la doctrina" (1970, p. 259).
} 
Con todo, se ha tratado de una teoría a la que se le ha reconocido una gran utilidad práctica, porque, a pesar de las subjetividades, pareciera brindar una explicación intuitivamente acertada de lo que sucede en el mundo cuando afirmamos que un fenómeno es causa de otro.

Pero ¿es la causalidad adecuada una verdadera y genuina teoría sobre lo que conocemos como nexo causal? La alusión a criterios de selección normativa, como la probabilidad y las máximas de la experiencia, ha develado que la causa adecuada no hace un examen de causalidad puramente físico o naturalístico, sino que, por el contrario, parezca más una herramienta de selección de la causa jurídicamente relevante, a partir de un conjunto dado de causas naturales. Puesto en otros términos, la causalidad adecuada no responde cuáles son las causas físicas o naturales de un determinado evento, sino que brinda unos parámetros conforme a los cuales se puede escoger, dentro de un determinado grupo de causas, cuál es la que resulta jurídicamente más relevante.

No en vano, Pizarro señala, por ejemplo, que,

más allá de las objeciones, la doctrina de la relación causal adecuada tuvo el mérito de fundar sobre bases razonablemente objetivas, superadoras del empirismo reinante hasta ese momento, un criterio de delimitación de imputación. No es, en verdad, como bien se ha dicho, una genuina teoría causal, en tanto no luce orientada a determinar si un elemento de hecho es la causa de un resultado. Su finalidad es más específica: establecer si determinados hechos deben ser considerados relevantes, desde una perspectiva jurídica, para formular la imputación de sus consecuencias a una determinada persona. La teoría de la causalidad adecuada es, en esencia, una teoría de la imputación objetiva, que permite con unos criterios normativos más o menos ciertos, cuando un resultado puede ser atribuido a un comportamiento (2006, p. 99).

Así, la causa adecuada pareciera ser idónea para resolver la pregunta por cuál es la causa jurídicamente relevante y no para esclarecer cuándo un fenómeno es causante de otro, en el sentido natural de la expresión 'causa'. Esto ha sido claramente entendido en otros ordenamientos jurídicos en los que la adecuación es comprendida en su justa dimensión, esto es, como un criterio de imputación o selección causal y no como un derrotero para determinar la causalidad natural. Así se ha hecho, por ejemplo, en España, Alemania o, incluso, en los 
Principios de Derecho Europeo de la Responsabilidad (PETL, por su sigla en inglés), que reflejan el estado más avanzado del debate.

$\mathrm{El}$ inconveniente, sin embargo, es que en Colombia este aspecto no ha sido diáfanamente aprehendido. En nuestro contexto local, la teoría de la causalidad adecuada ha sido estudiada y aplicada como un criterio de causalidad fáctica o natural, y no como una forma de imputación o selección de causas. Con ello, se ha desfigurado su alcance real, lo que ha conducido a que, en ocasiones, lleve a resultados inverosímiles o contraintuitivos. Un ejemplo puede resultar muy claro para ilustrar esta problemática.
A le da a B un golpe en la cabeza,insuficiente para provocar una lesión en un ser normal. Pero ocurre que B está afectado de una debilidad congénita de los huesos del cráneo y ese golpe le basta para matarlo. El resultado se produjo pues, pese a que el acto que ha sido la condición de ello no debía normalmente tener semejante efecto. La teoría de la causalidad adecuada conducirá a considerar la debilidad particular de los huesos del cráneo de B como un evento excepcional, y a con- siderar desde luego que el acto de A no es la causa del daño porque esta consecuencia no era previsible (Tamayo Jaramillo, 2007, p. 379).

Sin embargo, la intuición más elemental llegaría a la solución justamente opuesta: el golpe, independientemente de la situación atípica o anormal, es la causa fáctica del daño producido sobre B. Cosa distinta es si dicha causa resulta jurídicamente relevante a efectos de comprometer su responsabilidad, pero lo cierto es que, desde una perspectiva estrictamente causal, el impacto en el cráneo fue el que condujo al resultado. El problema es que, en cualquier caso, esa no es la respuesta a la que llega la causalidad adecuada. De manera contraintuitiva, como se mencionó, este criterio causal indicaría que el golpe no fue la causa del daño. Por esta falencia, algunos teóricos se han encargado de agregarle a la causalidad adecuada elementos que permitan sopesar antecedentes que solo de forma anormal o azarosa producen el resultado. De ahí que se hayan añadido aditamentos que, con la ayuda que las ciencias forenses 
prestan a este propósito, permiten que aun en esos raros casos, y junto con la 'lógica de lo razonable' (Recasens), dichos eventos puedan esclarecerse. ${ }^{27}$

No obstante, estos aditamentos, de una parte, no han resuelto el problema en la práctica, comoquiera que no se puede inventar un nuevo criterio para la causalidad adecuada con cada situación particular que surge en el mundo fáctico; pero, además, tampoco han sido capaces de resolver el problema de fondo, cual es el verdadero enfoque de la adecuación como un criterio de selección de causas (imputación) y no como un derrotero para determinar la causa real o causa de hecho.

Esta circunstancia nos permite entonces afirmar que, en la actualidad, ordenamientos como el colombiano enfrentan una verdadera crisis de la causalidad. Las teorías tradicionales se han mostrado insuficientes para resolver muchos de los problemas que, en la práctica, suponen los problemas de la responsabilidad civil. De hecho, la concepción más difundida hoy en día, que es la causalidad adecuada, no solamente está desenfocada desde su perspectiva teórica - comoquiera que es tratada como una teoría de la causalidad fáctica cuando, en realidad, surge como un criterio de imputación-, sino que, además, conduce a resultados contraintuitivos que han llevado a que se le sumen millones de criterios casuistas que, en general, reflejan el fracaso de la teoría como una versión explicativa de la causalidad.

Esto demuestra la necesidad de incentivar entonces una reingeniería significativa del concepto de causalidad en los ordenamientos que, como el colombiano, presentan los problemas antes descritos. En la propuesta que se esboza a continuación, se propone dicha reingeniería, la cual parte de adoptar ciertas figuras que ya existen en el derecho comparado y que podrían solucionar varios de los problemas antes descritos.

\footnotetext{
${ }^{27}$ Sobre la teoría formulada por Recasens, el profesor Tamayo Jaramillo dice: "El nexo causal se puede afirmar científicamente, pero su inexistencia o ruptura jurídica no siempre se puede decidir exclusivamente con criterio científico. En ese sentido pensamos que la teoría del logos propuesta por Luis Recasens Siches y por Chaïm Perelman es de gran utilidad en la solución de este problema. De acuerdo con dicha teoría, cuando el juez debe decidir un proceso de responsabilidad civil no puede condenar a quien no haya causado el daño; pero no es lógico que desde el punto de vista de lo razonable excluya ciertos eventos que, aunque participaron físicamente en la producción del daño, jurídicamente deben considerarse extraños al hecho. El error de la doctrina tradicional consiste en olvidar que se están juzgando conductas humanas y que, por tanto, el buen sentido deber orientar al fallado al momento de decidir si la conducta del agente es o no una causa del daño" (2007,p. 381).
} 


\subsubsection{Causalidad de hecho y causalidad de derecho. Hacía una teoría de la imputación objetiva ${ }^{28}$}

El primer eje de la propuesta tiene que ver con la incorporación de una distinción estructural: la que diferencia entre causalidad de hecho y causalidad de derecho, más propiamente denominada imputación objetiva. El derecho de daños colombiano no conoce formalmente esta oposición entre causalidad de hecho y causalidad de derecho. Como se evidenció previamente, la aplicación de la teoría de la causa adecuada como esquema dogmático de causalidad fáctica o natural da lugar a múltiples equívocos, los cuales pueden zanjarse a partir de esta diferenciación. Al introducir la imputación en el estudio de la causalidad fáctica, como sucede bajo la teoría de la causa adecuada cuando es empleada confusamente, se presentan los resultados absurdos, desde el punto de vista causal, que se expusieron previamente y que hacen que esta construcción dogmática no emerja como la ideal para adelantar el juicio de causalidad. ${ }^{29}$

De ahí que en diferentes latitudes se haya propugnado por la distinción entre causalidad de hecho y causalidad de derecho, aunque esta no sea la denominación más acertada. Con ello se procura evitar la confusión teórica y los resultados contraintuitivos que se presentan cuando una teoría propia de la causalidad de derecho o imputación objetiva — como es la teoría de la causa adecuada - es empleada como criterio para dilucidar la causalidad fáctica, de hecho o meramente naturalística.

${ }^{28}$ Como lo hace la doctrinante española Múrtula, es importante apuntar que "no está demás señalar en este punto que no debemos confundir la llamada 'responsabilidad objetiva o sin culpa' con la teoría de la 'imputación objetiva'. Así, mientras que esta última resuelve la relevancia jurídica de los elementos causales, una vez verificado el nexo causal (de acuerdo con la teoría de la equivalencia de las condiciones), a través de criterios normativos por los cuales un resultado puede ser atribuible a un comportamiento; la responsabilidad objetiva actuaría a posteriori en el juicio de responsabilidad, atribuyendo la responsabilidad al sujeto en función del riesgo creado con su actividad, que a su vez le reporta beneficios” (2005, p. 84).

${ }^{29}$ Dice Fernando Pantaleón, citado por Santos Ballesteros, que "el derecho no puede sino partir del concepto de causalidad propio de la lógica y de las ciencias de la naturaleza: la llamada concepción nomológico-funcional de la causalidad. Los operadores jurídicos no son productores, sino consumidores de leyes causales. Por ello puede afirmarse que la decisión sobre la existencia o no de la relación de causalidad es una cuestión de hecho libre de valoraciones específicamente normativas. Por el contrario, el problema de la imputación objetiva - la función de cuyos criterios es evitar que sean puestas a cargo del responsable absolutamente todas las consecuencias de las que su conducta es causa- es una cuestión puramente jurídica, un problema de valoración a resolver con las pautas más o menos precisas, ofrecidas por el sistema normativo de responsabilidad. No es correcto, por tanto, considerar las que verdaderamente son teorías de la imputación objetiva — entre ellas la mal llamada teoría de la causalidad adecuada— como si se tratara de teorías sobre la relación de causalidad" (2013, p. 376). 
Esta dicotomía propone entonces distinguir entre la causalidad de hecho y la causalidad de derecho para indicar que el examen causal debe partir, en un primer estadio, de la verificación fáctica del nexo - o verificación naturalística, fundamentada en los criterios de la ciencia y de la física- (causalidad de hecho) y, una vez determinado el conjunto de causas fácticas, seleccionar aquella o aquellas que resulten jurídicamente relevantes (causalidad de derecho) (Martín Casals, 2011).

Puesto en otros términos, esta es una teoría que le indica al intérprete que el estudio de la causalidad no se agota en la aplicación de una sola fase, sino que, por el contrario, requiere de dos etapas o estadios: uno primero, en el que se determina si fácticamente un suceso puede ser considerado como causa del otro (causalidad de hecho), y otro en el que se escogen, de las causas fácticas, aquellas que revisten importancia jurídica (causalidad de derecho) (Spier, 2012, pp. 79 y ss.). Este último estadio de selección es también conocido como 'imputación objetiva' en la medida en que determina cuándo un resultado dañoso, además de ser originado fácticamente en un determinado suceso o actuación, le es también imputable objetivamente a dicha actuación, esto es, le es atribuible en términos jurídicos.

Ahora bien, para determinar los criterios conforme a los cuales debe analizarse la causalidad de hecho y la causalidad de derecho, existen múltiples posturas. Con todo, la más difundida indica que la primera de las causalidades (causalidad de hecho) debe analizarse conforme al test sine qua non (que es el que emplea la equivalencia de las condiciones, antes explicada), mientras que la segunda (causalidad de derecho) se mira conforme a la causalidad adecuada. Así las cosas, para los ordenamientos en los que existe esta postura, lo primero que debe hacer el operador jurídico es determinar qué sucesos pueden considerarse como causa conforme a la regla sine qua non para luego seleccionar, de ese conjunto de causas naturales, cuál es la causa jurídicamente relevante (imputación objetiva) (Gil Botero, 2012, pp. 484 y ss.), de acuerdo con la causalidad adecuada.

Esta es, en esencia, la teoría de la imputación objetiva, ${ }^{30}$ en la cual, en palabras de Enrique Gil Botero,

\footnotetext{
${ }^{30}$ Sobre el origen de la imputación objetiva, se dice que "se encuentra en la escuela filosófica funcionalista planteada inicialmente por Jeremy Bentham (desde el utilitarismo), y luego fue retomada y desarrollada por el profesor Niklas Luhman, quien desarrolló la teoría de los sistemas sociales y, por lo
} 
una vez constatada o verificada la existencia de un daño, es indiscutible que este tuvo una génesis material o causal, hecho que es irrelevante para el derecho, precisamente porque se mantiene en el plano de las ciencias naturales, es decir, en relación causa-efecto. Por el contrario, verificada la existencia de un daño desde la dimensión jurídica, lo relevante es establecer a quién es atribuible esa afectación que sufre una determinada persona en sus derechos, bienes o intereses legítimos.

Es precisamente en ese específico escenario donde el término imputación supone un análisis bifronte o dual consistente en la verificación de que el daño es tanto fáctica (imputatio facti) como jurídicamente (imputatio iure) imputable. La imputación fáctica tiene como propósito determinar si en el plano material, mas no necesariamente causal,

tanto, la importancia de asignación de roles a cargo de los asociados en una organización de personas. Esta visión funcionalista surge como una respuesta a la teoría del finalismo penal cuyo principal defensor fue Hans Welzel, para quien la voluntad y el querer del sujeto de derecho responsable del daño se incorpora al concepto de acción [...] motivo por el cual pasó a ser conocida como la 'teoría final de la acción', cuyo sustrato principal se hallaba en las teorías causales de las ciencias naturales o empíricas, consideración adicional por la que se defendía bajo este paradigma una imputación netamente subjetiva (imputación subjetiva) fundamentada única y exclusivamente en la cognoscibilidad y exigibilidad esperada del sujeto — aspectos pertenecientes al fuero interno del actor del daño o del delito- Esta perspectiva, como lo destaca la doctrina, consistió en el desplazamiento que generó el positivismo naturalístico en el derecho penal respecto de la causalidad propia de las ciencias exactas, en donde no caben hechos indiscutibles, sino únicamente los comprobables materialmente" (Gil Botero, 2013, pp. 478-479). Sobre el camino que ha seguido esta teoría, Ortiz Gómez enseña: "Esta distinción fue hecha por primera vez para el derecho civil por el alemán Karl Larenz. La teoría, tal como la conocemos hoy, fue recogida por el penalista alemán Gunter Jakobs, y se basa en el principio de confianza: suponemos que cada uno de los actores sociales hace lo que tiene que hace, según Jakobs: 'Si en todo contacto social todos hubiesen de considerar todas las consecuencias posibles desde el punto de vista cognitivo, la sociedad quedaría paralizada. No se construiría ni se matricularía ningún automóvil, no se produciría ni se serviría alcohol, etc., y ello hasta el extremo de que a la hora de pagar sus deudas todo el mundo debería prestar atención a que el acreedor no planease realizar algo ilícito con el dinero recibido'. Así las cosas, Jakobs parte de la necesidad de que cada persona actúe de acuerdo con su función social. La teoría del imputación objetiva fue traída al derecho civil por el profesor Fernando Pantaleón en 1990. Advierte que el tema de causa no es un problema jurídico, sino de hecho, y así las cosas, el problema de la causa es radicalmente distinto de la reflexión jurídica de poner a cargo de una persona una conducta como obra de su autor. Lo anterior significa que los abogados no podemos inventarnos la causalidad, porque eso sería tanto como desconocer lo que ocurre en el mundo real; sería inventar un universo paralelo donde todo se explicara jurídicamente: los operadores jurídicos no son 'productores' sino 'consumidores' de leyes causales. Dado el reciente planteamiento de la teoría del derecho civil, esta debe entenderse como una teoría en construcción, [...]" (2010, p. 328). 
el daño es atribuible o no a un sujeto de derecho. Así las cosas, antes de abordar el análisis de la imputación jurídica o el fundamento de la responsabilidad, es imprescindible que la lesión o afectación antijurídica esté radicada en cabeza de la entidad o del sujeto pasivo de la relación.

Una vez constatado lo anterior, es posible abordar el análisis sobre la imputación jurídica, esto es, si existe o no un fundamento normativo que concrete, en el caso específico, la obligación de resarcir el daño antijurídico. En otros términos, la imputación fáctica - $-\mathrm{y}$ con ella la imputación objetiva del daño- consiste en un estudio retrospectivo que recae sobre la acción u omisión del sujeto, mientras que la imputación jurídica supone la realización de un análisis prospectivo y netamente normativo dirigido a determinar si, una vez establecida la atribución material del daño, existe o no el deber jurídico — subjetivo u objetivo- de resarcir el perjuicio.

Así mismo, resulta pertinente destacar que el hecho de que la imputación fáctica tenga un sustrato o contenido material no quiere significar que esté desprovista de conceptos o construcciones normativas o jurídicas y, por lo tanto, es allí donde la imputación objetiva y todos sus elementos delimitadores se conectan para suministrar una serie de herramientas a la hora de valorar cuándo es imputable o no un daño (Gil Botero, 2013, pp. 474-475).

Nótese entonces cómo se parte de un escenario dicotómico en el que se diferencia entre dos estadios de análisis ya explicados: el de la causa de hecho o causalidad fáctica, que responde a la cuestión de si un determinado fenómeno es, desde el punto de vista naturalista, el detonante de un resultado, para luego pasar a la fase de la causa de derecho o imputación objetiva, que sirve para seleccionar cuál es la causa jurídicamente relevante dentro del consabido grupo de causas naturalistas o de hecho. ${ }^{31}$

\footnotetext{
31 Sobre esta dicotomía se ha afirmado, desde lo penal, que "la imputación objetiva, en sus inicios, surge vinculada al problema de la teoría de la relevancia típica que aparece en la dogmática neoclásica, neokantiana, caracterizada fundamentalmente por el llamado dualismo metodológico que, al contrario de lo que acontecía con el método naturalista, afirmó que uno era el método de las ciencias naturales y otro el de las ciencias sociales, pues al paso que aquellas se soportan en causalidad, en estas su suporte es la filosofía de los valores. Con esta separación la dogmática neokantiana hizo una yuxtaposición del valor
} 
Ahora bien, para acometer el primero de los estadios del análisis, esto es, el de la causalidad de hecho, se decía entonces que se requiere de un criterio que permita determinar, con cierta fiabilidad, cuáles son los sucesos que desde la óptica meramente fáctica o científica pueden considerarse como causas del resultado. Para ello se ha recurrido entonces al que pareciera ser el test más idóneo, que es el de la conditio sine qua non, empleado por la teoría de la equivalencia de las condiciones.

Ciertamente, como ya se puso de presente en un segmento precedente, aunque este criterio ha sido criticado como teoría predominante de la causalidad, ha demostrado ser de gran utilidad cuando se le emplea única y exclusivamente con el propósito de verificar cuáles son las causas físicas o naturales de un fenómeno. El test sine qua non, basado en el explicado juicio contrafáctico, es muy apropiado para identificar todo el conjunto de variables que hicieron posible la ocurrencia de un suceso, comoquiera que permite determinar cuándo, al omitir una de tales variables, desaparece el resultado. En ese sentido, desde un punto de vista estrictamente físico, se erige como una teoría muy sugestiva.

Puesto en otros términos, al emplear un juicio contrafáctico, el test sine qua non permite dilucidar, definitivamente, qué factores han sido decisivos en la producción del resultado, comoquiera que evalúa en ausencia de cuáles de ellos desaparece la consecuencia analizada. Este razonamiento tan básico conduce, en últimas, a esclarecer el universo de causas determinantes en el acaecimiento del desenlace final, lo que hace de esta idea un postulado muy sugestivo en lo que a la causalidad fáctica se refiere.

frente a la realidad, haciendo desaparecer la fusión entre el ser y el deber ser que, más adelante, reaparece con la dogmática finalista al entender la acción como una unidad de sentido en que se funde, nuevamente, el valor con el ser, tal como la entendía Wezel. [...] Otra repercusión de la dogmática neokantiana, con su dualismo metodológico, fue la teoría de la relevancia típica que parte de la teoría causal de la equivalencia de las condiciones, en donde todas las condiciones contribuyen por igual a la producción del resultado en la medida en que si se suprime, mentalmente, una de ellas el resultado no se consigue, de conformidad con la teoría de la conditio sine qua non. Pero si bien para la teoría de la relevancia típica todas las condiciones tienen idéntico valor desde el punto de vista causal, no todas las condiciones son relevantes para el tipo penal. [...] En principio, entonces, la teoría de la imputación objetiva surge como un desarrollo de relevancia típica vinculada, inicialmente, a solucionar fundamentalmente el problema de la atribución de resultados, es decir, determinar si se puede imputar el resultado a una determinada persona, tal como en sus inicios la concibió Roxin" (Villanueva, 2011, pp. 55-57). 
El problema se presenta cuando se le emplea como un criterio jurídico, toda vez que, al evaluar todas las posibles causas como equivalentes, no permite seleccionar aquella que es jurídicamente relevante y, por el contrario, propicia un regreso al infinito. Por eso se ha dicho que el test sine qua non es muy efectivo para esclarecer el conjunto de causas físicas de un hecho, pero muy pobre para determinar la causa que interesa al derecho. También por esto es por lo que es un criterio ideal para la causalidad de hecho, aun cuando no para la imputación objetiva o causalidad de derecho, que es justamente lo que se ha hecho en otros sistemas comparados y lo que se propone en este escrito.

No en vano expresa Javier Tamayo Jaramillo:

Cualquiera que sea la teoría de la causalidad que se acoja, lo cierto es que [...] siempre es indispensable que el fenómeno que se estudia como posible causa sea conditio sine qua non del daño. Es decir, desde el punto de vista jurídico, solo se considera causa del daño aquel fenómeno sin el cual el daño no se habría producido. Ello significa que si, en el caso concreto, el juez llega a la conclusión de que el daño de todas maneras se habría producido así no hubiera concurrido la culpa del demandado este no se considera causante de ese daño (Tamayo Jaramillo, 2007, p. 384). ${ }^{32}$

El empleo del test sine qua non como criterio de imputación fáctica es retomado, por lo demás, por la experiencia comparada, que reconoce las bondades de distinguir entre causa de hecho y causa de derecho, y, a su turno, de emplear el mencionado test como el idóneo para dilucidar la primera de las hipótesis. Así lo han hecho, por ejemplo, los Principios de Derecho Europeo de la Responsabilidad Civil en su artículo 3:101 (Conditio sine qua non), el cual indica que "una actividad o conducta (en adelante actividad) es causa del daño de la víctima si, de haber faltado la actividad, el daño no se hubiera producido". 33

\footnotetext{
32 En el mismo sentido, Salvador Coderch y Fernández Crende apuntan: "En una primera aproximación, la causalidad, entendida como causalidad de hecho, se determina por mediación del criterio de la conditio sine qua non (but-for test): hay causalidad cuando el daño no hubiera ocurrido de no haberse realizado la conducta, por acción u omisión del demandado" (2006, p. 3).

${ }^{33}$ Sobre las tendencias europeas en la materia, el profesor Patrice Jourdain afirma: "Le droit français ne définit pas le lien de causalité. Il n'indique explicitement sa préférence pour aucune des théories proposées par
} 


\begin{abstract}
Ahora bien, en lo que tiene que ver con la segunda fase del análisis de la causalidad, esto es, con la causalidad de derecho o imputación objetiva, ha dicho el profesor Yzquierdo que
\end{abstract}

resulta desde esta perspectiva una auténtica cuestión de derecho [...]. Una vez decidido que existe relación causal, resta ver si, existiendo varios protagonistas en la secuencia, ha de ser uno u otro el que responda, y de cuántas consecuencias. Y para ello podrán servir el criterio de la adecuación, el de la eficiencia, el de la proximidad o el que sea. Pero esto es ya un problema de imputación objetiva, no de causalidad. Ya no se trata de una cuestión dejada a la exclusiva soberanía del tribunal de instancia, sino de una auténtica quaestio iuris cuyo tratamiento uniforme corresponde adoptar precisamente al Tribunal Supremo (2010, p. 329).34

Así, en lo que consiste la imputación objetiva o causalidad de derecho es, esencialmente, en una etapa de selección; una etapa en la que, dado un conjunto de causas físicas del resultado, se escoge cuál de todas ellas es la que resulta

la doctrine. Les projets de réforme ne le font pas davantage, les rédacteurs ayant refusé de prendre un parti qui aurait risqué d'être aussitôt démenti par les tribunaux, eu égard à leur pratique habituelle. À cet égard les projets européens tranchent nettement avec notre droit. Les PETL énoncent à l'art. 3:101 : 'Est considérée comme cause du dommage subi par la victime toute activité ou conduite (ci-après « activité ») en l'absence de laquelle le dommage ne serait pas survenu' et les auteurs du DCFR sont dans le même sens, dans l'art. 4:101 : 'Une personne cause à autrui un dommage juridiquement pertinent si ce dommage doit être considéré comme une conséquence de la conduite de cette personne ou de la source de danger dont la personne est responsable'. Néanmoins, derrière cette différence formelle, on retrouve une idée semblable. Les textes européens optent tous deux pour la doctrine dite de l'équivalence des conditions ou de la condition sine qua non, que ne renie nullement le droit français. Bien des auteurs estiment d'ailleurs quelle représente dans la jurisprudence française la tendance dominante, à défaut de constituer un véritable principe. Souvent en effet les juges commencent par élaborer un raisonnement contrefactuel (ou but for test) en se demandant si, sans le fait (c’est-à-dire dans un scénario contraire à celui de l'espèce), le dommage se serait quand même produit. La causalité ne sera admise quien cas de réponse négative, cèst-à-dire si le fait apparaît comme une cause nécessaire du dommage. De ce point de vue, le caractère plus ou moins direct du lien comme la concurrence d'autres causes du dommage, simultanées ou successives, sont normalement sans incidence. Au stade des principes, droit français et projets européens convergent largement"(2014).

${ }^{34} \mathrm{El}$ profesor Ortiz Gómez afirma que "la imputación objetiva en el derecho civil propone una serie de criterios que llevan a no imputar la conducta al agresor. Dicho de otra manera: los criterios expuestos a continuación son criterios de exclusión de la imputación, de modo que si se da cualquiera de ellos, se llegará a la conclusión de que el agresor causó físicamente los daños, pero que jurídicamente no le son imputables y en consecuencia no responde, dado que los daños no resultan directos" (2010, p. 329). 
jurídicamente relevante y, de contera, la que puede llevar a que se comprometa la responsabilidad. Entonces,

su aplicación sirve para negar la equiparación absoluta entre la prueba de la relación de causalidad — strictu sensu o causalidad fáctica o material - y la atribución de responsabilidad civil. Conforme esta teoría, que goza cada día de mayor predicamento en la doctrina civil, el problema causal se reduce —o se extiende - a través de diversos criterios de imputación (como el de exclusión del 'riesgo general de la vida', o el criterio de la 'prohibición de regreso', etc.), que si bien no son dogmas de contornos perfectamente dibujados (sino que tienen un cierto halo de imprecisión, pudiéndose presentar, además, de una manera interrelacionada y no excluyente), son, sin embargo, instrumentos útiles para configurar la relación de causalidad (Múrtula, 2005, p. 84).35

Ahora bien, como lo indica la profesora Virginia Múrtula Lafuente, para la selección de las causas jurídicas relevantes se puede emplear toda una serie de parámetros normativos, en los términos antes expuestos.

Así, por ejemplo, los citados Principios de Derecho Europeo de la Responsabilidad Civil, tomando la distinción entre causalidad de hecho y causalidad de derecho, contienen en su artículo 3:201 los criterios de imputación objetiva de un daño. En dicha norma, se ordena

que si una actividad es causa en el sentido de la sección 1 de este capítulo [Conditio sine qua non], la cuestión de si puede ser imputada a una persona y en qué medida depende de factores como los siguientes:

a) la previsibilidad del daño para una persona razonable en el momento de producirse la actividad considerando, en especial, la cercanía en el tiempo y en el espacio entre la actividad dañosa y su consecuencia, o la magnitud del daño en relación con las consecuencias normales de tal actividad;

b) la naturaleza y valor del interés protegido (artículo 2:102);

${ }^{35}$ Sobre los diferentes criterios de imputación objetiva, se puede ver: Díez-Picazo (2007, pp. 372 y ss.), Gil Botero (2013, pp. 480 y ss.), Navarro (2013, pp. 200 y ss.), Ortiz Gómez (2010, pp. 329 y ss.), Salvador Coderch y Fernández Crende (2006, pp. 7 y ss.). 
c) el fundamento de la responsabilidad (artículo 1:101);

d) el alcance de los riesgos ordinarios de la vida; y el fin de protección de la norma que ha sido violada. ${ }^{36}$

\title{
De esto criterios de imputación objetiva, se hace especial mención al deno- minado criterio de la adecuación, consagrado en el literal a) del artículo ante- riormente mencionado, y en virtud del cual, tomando los postulados de la teoría de la causalidad adecuada,
}

\begin{abstract}
solo se puede imputar el daño a aquel cuya conducta resulta muy probable como causante del daño, según la reflexión hecha por un observador que deberá tener en cuenta los conocimientos especiales
\end{abstract}

\footnotetext{
${ }^{36}$ En el comentario que sobre el particular se hace a este artículo, se explica: "A los efectos prácticos, cada uno de los ordenamientos jurídicos europeos tenidos en cuenta acepta que el mero hecho de que se determine una conditio sine qua non entre un daño y una actividad no significa que todos y cada uno de los daños posteriores tengan que ser indemnizados por la persona responsable. Como ya se ha mencionado más arriba, esto parece cierto incluso con respecto a Bélgica y Francia. En el fondo, el resultado de las sentencias de los tribunales de ambos países no es significativamente diferente si lo comparamos con el de otros países objeto de análisis. La diferencia real entre los distintos ordenamientos jurídicos parece consistir en que algunos perciben la cuestión tratada por el artículo 3:201 como un instrumento jurídico carente de cualquier relación con ella. No obstante, (hablando en términos teóricos) con las excepciones que se acaban de mencionar, cada ordenamiento jurídico reconoce — por supuesto- que el cielo no puede ser el límite. Así pues, a efectos prácticos las diferencias son muy limitadas. Hemos intentado evitar los debates de este tipo distinguiendo entre la conditio sine qua non (sección 1) y el alcance de la responsabilidad (sección 2), que se encuentran juntos en el capítulo 3 (relación de causalidad). [...] El artículo 3:201 sólo entra en juego si el requisito de la sección 1 se cumple. Ello significa que una causa potencial, concurrente o alternativa puede ser suficiente. [...] Los factores mencionados en el artículo 3:201 letras a-e se han extraído de una seria de casos que a su vez están tomados de la jurisprudencia nacional o inspirados en ella. Esta lista no es exhaustiva. Por esta razón hablamos de 'factores como los siguientes'. En la mayoría de los casos operarán diversos factores: (a), (b) y (e) son probablemente los más importantes. Como regla general, la responsabilidad no puede establecerse fácilmente si el daño no era razonablemente previsible en el momento en que la actividad se llevó a cabo, mientras que se requiere una atribución cautelosa si el criterio mencionado en el apartador (e) no se cumple. No obstante, pueden aplicarse excepciones, por ejemplo en caso de dolo. Además, en especial en los casos de daños corporales (graves), puede resultar que se requiera una atribución más generosa para cumplir con las exigencias de la justicia. Esto último puede ilustrarse mediante los bien conocidos casos de la 'cáscara de huevo'. Este tipo de casos son relativamente raros y por esta precisa razón no son previsibles en la realidad. No obstante, este daño será imputable al responsable. Los factores relevantes pueden muy bien apuntar en direcciones distintas.Por ejemplo, el daño corporal merece una protección más intensa (artículo 2:102,párrafo 2). La responsabilidad objetiva (artículo 5:101) puede constituir una razón para que se sea reacio a imponer un alcance de la responsabilidad muy amplio. En estos casos - y en otros muchos- los factores relevantes tienen que ser ponderados unos con otros"(Ordoqui Castilla, 2011, pp. 98-100).
} 
con que contaba el agresor al momento de causar el hecho. Este observador debe considerar la cuestión ex ante. Si según el observador el hecho no es causa normalmente imputable a su autor, en ese sentido diríamos que no hay nexo jurídico entre la conducta (hecho) y el daño. Este criterio difiere de la teoría de la causalidad adecuada en quien hace la reflexión: se trata de un observador experto (Ortiz Gómez, 2010, p. 329).

El criterio de la adecuación permite acometer una adecuada selección de causas, a partir de parámetros que son de interés del derecho, como la normalidad y la previsibilidad. Así, en casos como el de la fragilidad ósea, antes comentado, se puede llegar a un resultado más coherente y sostenible: el golpe que se le propine a un sujeto que padezca esta enfermedad será, en definitiva, la causa física del resultado, aun cuando, desde la óptica de la imputación objetiva, no le será objetivamente imputable al autor, dada su anormalidad e imprevisibilidad.

Nótese cómo la distinción ofrece entonces indiscutibles ventajas:

En el ámbito colombiano, la jurisdicción de lo contencioso administrativo ha sido precursora de la aplicación de esta teoría al ámbito de la responsabilidad extracontractual del Estado. ${ }^{37}$ En reiterados pronunciamientos, el Consejo de Estado ha echado mano de la teoría de la imputación objetiva para señalar a las entidades estatales como responsables del daño e imponerles la obligación de reparar.

Así, en diversas sentencias ha precisado, al reconocer diferencia entre imputación fáctica e imputación jurídica, que

en cuanto a la imputación exige analizar dos esferas: a) el ámbito fáctico y b) la imputación jurídica, en la que se debe determinar la atribución conforme a un deber jurídico (que opera conforme a los distintos títulos de imputación consolidados en el precedente de la Sala: falla o falta en la prestación del servicio — simple, presunta y

\footnotetext{
37 Con todo, valga aclarar, por su génesis penal, que la imputación objetiva fue utilizada primariamente para la imputación de un resultado por los tribunales de dicha especialidad. Así, se ha dicho que "fue la Sala Penal del Tribunal Superior de Bogotá, jalonada por sentencias y salvamentos de voto del ex magistrado Abelardo Rivera Llano, el juez que empezó, desde 1994, a utilizar los criterios de imputación objetiva para resolver asuntos relacionados con delitos culposos [...]”(Villanueva, 2011, p. 133).
} 
probada—; daño especial — desequilibrio de las cargas públicas, daño anormal—; riesgo excepcional. Adicionalmente, resulta relevante tener en cuenta los aspectos de la teoría de la imputación objetiva de la responsabilidad patrimonial del Estado. [...] Sin duda, en la actualidad todo régimen de responsabilidad patrimonial del Estado exige la afirmación del principio de imputabilidad, según el cual la indemnización del daño antijurídico cabe achacarla al Estado cuando haya el sustento fáctico y la atribución jurídica. Debe quedar claro que el derecho no puede apartarse de las "estructuras reales si quiere tener alguna eficacia sobre las mismas". En cuanto a esto, cabe precisar que la tendencia de la responsabilidad del Estado en la actualidad está marcada por la imputación objetiva, título autónomo que "parte de los límites de lo previsible por una persona prudente a la hora de adoptar las decisiones". Siendo esto así, la imputación objetiva implica la 'atribución', lo que denota en lenguaje filosófico-jurídico una prescripción, más que una descripción. Luego, la contribución que nos ofrece la imputación objetiva, cuando hay lugar a su aplicación, es la de rechazar la simple averiguación descriptiva, instrumental y empírica de "cuando un resultado lesivo es verdaderamente obra del autor de una determinada conducta". [...]. Dicha tendencia es la que marcó el precedente jurisprudencial constitucional, pero ampliando la consideración de la imputación (desde la perspectiva de la imputación objetiva) a la posición de garante donde la exigencia del principio de proporcionalidad es necesaria para considerar si cabía la adopción de medidas razonables para prevenir la producción del daño antijurídico, y así se motivara el juicio de imputación. Dicho juicio, en este marco, obedece sin lugar a dudas a un ejercicio de la ponderación que el juez está llamado a aplicar, de tal manera que se aplique como máxima que "Cuanto mayor sea el grado de la no satisfacción o del detrimento de un principio, mayor debe ser la importancia de satisfacción del otro". [...] la responsabilidad extracontractual del Estado se puede configurar una vez se demuestre el daño antijurídico y la 


\title{
imputación (desde el ámbito fáctico y jurídico) (Consejo de Estado, sentencia del 19 de agosto de 2011). ${ }^{38}$
}

\begin{abstract}
${ }^{38}$ En el mismo orden de ideas, se pronunció el Consejo de Estado, al afirmar que "[...] si la ciencia jurídica parte del supuesto de atribuir o endilgar las consecuencias jurídicas de un resultado (sanción), previa la constatación de que una transgresión se enmarca en una específica proposición normativa, es evidente que el nexo causal por sí mismo deviene insuficiente para solucionar el problema de la atribución de resultados, tal y como desde hace varios años se viene demostrando por el derecho penal, lo que ha conllevado que se deseche el principio de causalidad a efectos de imputar un hecho, para dar aplicación a una serie de instrumentos e ingredientes normativos ( $v$ gr., el incremento del riesgo permitido, la posición de garante, el principio de confianza, la prohibición de regreso, etc.) dirigidos a establecer cuándo determinado resultado es imputable a un sujeto. Lo anterior, comoquiera que es posible que un determinado suceso tenga origen material en una específica conducta (causa material), pero las consecuencias del mismo sean atribuidas a un tercero ( $v$. gr., la responsabilidad por el hecho de las cosas, o por el hecho de otro" (Consejo de Estado, sentencia del 26 de marzo de 2009). En esta misma línea, en la sentencia del 9 de junio de 2010, se dio aplicación a la imputación objetiva en los siguientes términos: "En el caso concreto, el análisis de imputación desborda el plano de lo material y fáctico para ubicarse en un escenario normativo que se traduce, en sí mismo, en un ejercicio de imputación objetiva que permite determinar si el daño es o no atribuible al municipio demandado. En otros términos, si bien se desconoce la causa que dio origen a la lamentable muerte de Jhon Alexander Marín Moncada, lo que prima facie, desde el plano material, configuraría una ausencia de imputación respecto del Estado, lo cierto es que desde la perspectiva del derecho, el estudio de la misma enseña que ésta no sólo puede ser fáctica, sino también normativa, que, para el caso, se estructura en la dimensión de la imputación objetiva y, concretamente, de la omisión. En consecuencia, el hecho de que el daño tenga su génesis directa, material y causal en una acción ajena a la administración pública no quiere significar, en principio, que se haya configurado una causa extraña que exonere de responsabilidad, toda vez que aquél puede devenir imputable a esta última si su comportamiento fue relevante y determinante en el desencadenamiento del mismo, bien porque se contribuyó con una acción en la producción ( $v$. gr., con un aumento del riesgo permitido o un desconocimiento del principio de confianza), o si pudiendo evitarlo se abstuvo de enervar su generación, esto último, siempre y cuando se constate en estos eventos que la entidad demandada se encontraba en posición de garante, es decir, que de conformidad con el ordenamiento jurídico estuviera compelida a evitar el resultado. Por consiguiente, si bien la imputación fáctica tiene un sustrato material o causal, lo cierto es que no se agota allí, ya que dada su vinculación con ingredientes normativos es posible que en sede de su configuración se establezca que un daño en el plano material sea producto de una acción u omisión de un tercero o de la propia víctima, pero resulte imputable al demandado siempre que se constate la ocurrencia de cualquiera de los siguientes aspectos: i) con fundamento en el ordenamiento jurídico se tenía el deber de impedir la materialización del daño (posición de garante); ii) con su actividad se incrementó el riesgo permitido (creación de un riesgo jurídicamente desaprobado); o iii) se estaba dentro del ámbito de protección de una norma de cuidado"(Consejo de Estado, sentencia del 9 de junio de 2010). También, en sentencia del 5 de julio de 2012, el máximo tribunal contencioso administrativo imputó un resultado a partir de esta teoría. En ese sentido, reflexionó: "La imputación fáctica tiene como propósito determinar si en el plano material, mas no necesariamente causal, el daño es atribuible o no a un sujeto de derecho. Así las cosas, antes de abordar el análisis de la imputación jurídica o el fundamento de la responsabilidad, es imprescindible que la lesión o afectación antijurídica esté radicada en cabeza de la entidad o del sujeto pasivo de la relación. Una vez constatado lo anterior, es posible abordar el análisis sobre la imputación jurídica, esto es, si existe o no un fundamento normativo que concrete, en el caso específico, la obligación de resarcir el daño
\end{abstract}


Se evidencia en la jurisprudencia contencioso-administrativa que, a diferencia de lo aquí propuesto, el resultado, en sede imputación de derecho, ha desarrollado un conjunto de instrumentos para su atribución, entre los que se encuentran “i) el riesgo permitido; ii) el principio de confianza; iii) la posición de garante; iv) la acción a propio riesgo; v) la prohibición de regreso y vi) el fin de protección de la norma”, así el criterio de la adecuación, que en este trabajo se señala como el ideal para imputatio iuris, no es abordado en materia de responsabilidad del Estado.

De esta forma, para que el Estado sea responsable, no es necesario que su actuación, desde una prognosis póstuma, tenga como resultado normal o probable la causación del daño. Por lo que, en últimas, a partir de los títulos de imputación utilizados por el Consejo de Estado, la responsabilidad de este, desde la óptica de la relación causal, entendida como atribuibilidad del daño, es mucho más amplia de lo que sería de aplicar los predicamentos que en este texto se exponen.

Con todo, si bien esta teoría, a partir de la diferenciación entre una causa fáctica y una jurídica, logra superar gran parte de los inconvenientes que se presentaban en el pasado al utilizar los diferentes instrumentos teóricos que no contenían esta dualidad, lo cierto es que persisten aún problemas relevantes. Se le reprocha a la imputación objetiva "que no explique adecuadamente los casos de causalidad hipotética y alternativa, en este caso además hay un criterio de exclusión de imputación que puede agravar este último problema, a saber: el criterio del incremento del riesgo o de la conducta alternativa correcta" (Ortiz Gómez, 2010, p. 332).

\subsubsection{Problemas de sobredeterminación e incertidumbre causal}

Ahora bien, a pesar de las bondades propias de la distinción entre causalidad de hecho y causalidad de derecho, lo cierto es que subsisten algunas puntuales hipótesis que pueden representar casos problemáticos a la hora de dilucidar el vínculo de causalidad. Estas hipótesis, en general, se refieren a situaciones en las que el test sine qua non y los juicios contrafácticos resultan insuficientes

antijurídico En otros términos, la imputación fáctica — y con ella la imputación objetiva del daño— consiste en un estudio retrospectivo que recae sobre la acción u omisión del sujeto, mientras que la imputación jurídica supone la realización de un análisis prospectivo y netamente normativo dirigido a determinar si, una vez establecida la atribución material del daño, existe o no el deber jurídico — subjetivo u objetivode resarcir el perjuicio"(Consejo de Estado, sentencia del 5 de julio de 2012). 
para esclarecer, desde la perspectiva física o natural, si un fenómeno fue el detonante de otro.

Piénsese, por ejemplo, en el caso en que tres sujetos (B1, B2 y B3) disparan un arma de fuego en un campo de caza, hiriendo una de las balas a un deportista que corría por el sector, pero sin que se sepa, a ciencia cierta, cuál de los tres cazadores fue el que propinó la herida. En una situación como esta, se tiene una pluralidad de actividades, cada una de las cuales era suficiente para generar, por sí sola, la totalidad del daño, aun cuando no se sabe realmente cuál fue la que efectivamente lo irrogó.

$\mathrm{Al}$ aplicarse el test sine qua non, se observa entonces que no es posible determinar en ausencia de cuál actividad — si la de B1, B2 o B3 — se habría podido evitar la lesión y, de contera, tampoco se puede esclarecer quién es el causante fáctico de esta. Dicho tipo de inconvenientes han aflorado en la práctica y han conducido a adoptar cierto tipo de soluciones normativas que procuran evitar que, en estos casos, se llegue a la paladina injusticia de dejar a la víctima sin indemnización por la imposibilidad de acreditar la relación causal.

Pues bien, en este acápite, se tratarán dos de estos aspectos problemáticos: el de la denominada sobredeterminación causaly el de la causalidad incierta - $\mathrm{O}$ los problemas de causalidad alternativa - ${ }^{39}$ en aras de plantear un modelo de solución que también fue ya desarrollado por el derecho europeo y que, al parecer, es el criterio más difundido entre los comparatistas que se han dedicado a la cuestión.

\subsubsection{El problema de la sobredeterminación causal}

La sobredeterminación causal se presenta, esencialmente, cuando, existiendo una pluralidad de actividades, cada una de ellas habría podido causar el daño por sí sola al mismo tiempo. En este caso, “... la regla de la conditio [test sine qua non] no resuelve el problema porque daría lugar al resultado absurdo de que ninguna actividad puede haber sido la causa porque el daño igualmente se hubiera producido como resultado de la otra u otras actividades" (Martín Casals, 2011, p. 2). Ciertamente, si cada una de las actividades separadas y

\footnotetext{
${ }^{39} \mathrm{Al}$ respecto, Martín Casals pone de presente que la "idea contrafactual que está en la base de la conditio sine qua non no resuelve el problema de establecer si una actividad ha sido la causa de un daño ni en casos de sobredeterminación, como cuando existe causalidad concurrente, ni en casos de incertidumbre"(2011a,p. 1).
} 
autónomas hubiera sido suficiente, por sí sola, para la generación del daño, lo cierto es que la pregunta del juicio sine qua non sería siempre negativa: no se puede asegurar que, al eliminar alguna de las actividades, habría desaparecido el resultado, comoquiera que, en cualquier caso, subsistían otras que lo podrían generar.

Piénsese, por ejemplo, en el caso en que A dispara un misil de corta distancia, mientras que $\mathrm{B}$ dispara uno de larga distancia, y los dos misiles impactan el objetivo exactamente al mismo tiempo. En esta hipótesis, si se aplicara la regla de la conditio sine qua non, que proponemos para la verificación de la causalidad de hecho, se tendría que ni A ni B pueden considerarse como agentes causales del daño. En efecto, en el caso de A, es evidente que, aun omitiendo su proceder, subsiste el daño irrogado — en virtud del misil lanzado por B-, de modo tal que él no es causa de este de acuerdo con la teoría del juicio contrafáctico. Idéntica es la situación de B: incluso si él no incurriera en la conducta, el resultado subsistiría — dado el disparo de A-, por lo que él no podría ser considerado como detonante de este.

Así, la sobredeterminación llevaría entonces a un absurdo: a pesar de que los dos misiles impactaron en el objetivo, al haberlo hecho al tiempo - y es importante enfatizar en que la sobredeterminación requiere que los resultados se produzcan al tiempo-, el test sine qua non llevaría a considerar que la víctima no tiene derecho a la indemnización, porque ni A ni B pueden ser considerados como causa fáctica del daño. Naturalmente, esta es una respuesta contraintuitiva.

Para solucionarlo, hace falta adoptar una previsión normativa de cómo solucionar el problema causal que se presenta. Por eso es por lo que los instrumentos comparados lo que suelen hacer es matizar la regla sine qua non para los casos de sobredeterminación y establecer que, en estos, todos los intervinientes serán considerados como causa de la lesión. Así se evita llegar al resultado absurdo antes mencionado. En ese sentido, es ilustrativo el artículo 3:102 de los Principios de Derecho Europeo de la Responsabilidad Civil, que, en relación con las causas concurrentes (o sobredeterminación causal), establece que "en caso de una pluralidad de actividades, si cada una de ellas hubiera causado el daño por sí sola al mismo tiempo, se considerará que cada 
actividad es causa del daño de la víctima". ${ }^{40}$ Del mismo modo lo hace el Restatement norteamericano, que aconseja adoptar esta previsión.

De esta forma se supera el escollo de la sobredeterminación a favor de la víctima, pues, contrario al resultado que se lograría inicialmente de librar a todos de responsabilidad a partir del juicio contrafáctico, la solución por la que se opta es la de tener a todos los agentes como causantes del daño, generando responsabilidad en cabeza de todos de manera solidaria. ${ }^{41}$ Así, la víctima podrá accionar en contra de cualquiera de ellos para pedir la indemnización a la que tiene derecho de acuerdo con el daño que ha sufrido, sin que pueda alegar el demando el hecho de los demás para librarse de su responsabilidad. ${ }^{42}$

Para concluir, vale la pena resaltar dos aspectos adicionales: en primer lugar, para que se presente realmente el problema de la sobredeterminación causal, es preciso que cada actividad haya sido capaz de generar el daño al mismo tiempo. Si una lo genera primero y la otra lo hace después, será evidente que el juicio contrafáctico o test sine qua non resolverá el problema, comoquiera que será solamente el primer hecho dañoso el que se considerará como causa.

De otra parte, no se puede confundir la sobredeterminación con el problema de incertidumbre causal, que se explicará en el acápite siguiente. A diferencia de este, en el caso de la sobredeterminación existe certeza sobre la

\footnotetext{
${ }^{40}$ Sobre esta solución, el profesor Jourdain expresa: "Lorsque des activités indépendantes prises isolément auraient, dans le même temps, suffi à causer le même dommage, les PETL décident que chacune des causes dites 'concurrentes' doit être retenue comme cause du dommage. Cette solution qui est conforme à notre jurisprudence, mais aussi à celles des autres systèmes juridiques, prend ses distances avec le test de la condition sine qua non car en l'absence l'une ou l'autre activité le dommage se serait quand même produit; mais la dérogation est nécessaire car à défaut aucune cause ne serait retenue" (2014).

${ }^{41} \mathrm{Tal}$ solución se encuentra en el derecho colombiano en el artículo 2344 del Código Civil: "Si un delito o culpa ha sido cometido por dos o más personas, cada una de ellas será solidariamente responsable de todo perjuicio procedente del mismo delito o culpa, $[\ldots]$ ”. Jorge Baraona González afirma que, en los casos de pluralidad de autores de un daño indemnizable, "los tribunales franceses tienden a condenar in solidum, sin perjuicio de las excepciones legales. Como presupuesto básico se exige que el daño debe ser único y provenir de diversas personas que convergen en un solo daño, sin importar si la culpa de los responsables es concurrente o sucesiva" (2004, p. 221).

${ }^{42}$ Señala la profesora Múrtula que "en estos casos, en la medida en que se puede eliminar mentalmente cualquiera de los factores sin que se altere el resultado, éste resulta imputable a todos. Aunque podría argumentarse que en ausencia del hecho individual de cada partícipe la consecuencia hubiera igualmente acaecido, esto no es admisible como defensa, pues si así fuese al invocarla cada uno o ninguno sería responsable del perjuicio" (2005, p. 68).
} 
entidad de cada una de las causas para provocar el daño y es por la concurrencia temporal (por generar la consecuencia perjudicial al mismo tiempo) que se les reconoce a todas como causas en las mismas condiciones. ${ }^{43}$ Aquí el problema no es, en estricto sentido, que no se sabe a ciencia cierta qué conducta causó el daño; no: aquí es claro que ambas conductas lo causaron, lo que sucede es que, al hacerlo al mismo tiempo, el test sine qua non no puede esclarecer cuál es el detonante del resultado final.

\subsubsection{El problema de la incertidumbre causal}

El segundo grupo de casos problemáticos tiene que ver con la denominada incertidumbre causal. Bajo este rótulo se agrupa toda suerte de hipótesis en las que no se puede determinar, con la suficiente certidumbre, quién fue el agente causante del daño. Puesto en otros términos, se trata de situaciones en las que no se sabe a quién imputarle fácticamente el resultado, porque no se puede, desde el punto de vista epistemológico, determinar de dónde provino el resultado.

Es importante señalar que la incertidumbre a la que se hace referencia en este punto no es a la incertidumbre epistemológica o evidenciaria, esto es, a la resultante de la imposibilidad de probar quién ha sido el causante del daño. En estos casos, la incertidumbre es indeterminista u ontológica, es decir, no se refiere a la imposibilidad de probar, sino a la imposibilidad objetiva de saber quién fue el detonante causal. Así las cosas, los ejemplos que se citan a continuación no se refieren a casos de dificultad probatoria, sino a situaciones en las que es imposible, fácticamente hablando, determinar qué acción constituye la causa del daño.

Pues bien, varias situaciones encajan en este tipo de supuestos, a saber:

La denominada causalidad alternativa con incertidumbre de agente o causante del daño no identificado, "que se produce cuando nos encontramos ante diversos hechos que, aunque poseen individualmente aptitud para producir un daño, éste ha sido obra exclusiva de uno solo de los partícipes. El hecho dañoso

${ }^{43}$ En los comentarios a este artículo en los Principios de Derecho Europeo de la Responsabilidad Civil, se destaca "que es irrelevante si las actividades tuvieron lugar al mismo tiempo o no; lo decisivo es que causaron el daño al mismo tiempo. Ello puede mostrarse mediante un ejemplo algo rocambolesco. D1 lanza un misil de larga distancia y D2 uno de corta distancia. Ambos misiles impactan con las instalaciones de $\mathrm{P}$ al mismo tiempo. El lanzamiento no tuvo lugar al mismo tiempo, mientras que los misiles alcanzan su objetivo exactamente al mismo tiempo. Lo decisivo es esto último"(Spier, 2012, pp. 79 y ss.). 
aparece atribuible a uno u otra persona dentro de un conjunto de ellas de manera excluyente..." (Múrtula, 2005, p. 69), pero no es posible determinar, a ciencia cierta, a quién se le puede atribuir.

Puesto en otros términos, es una hipótesis que se presenta cuando, en el caso de una pluralidad de actividades, cada una de ellas ha sido suficiente, por sí sola, para causar el daño, pero es dudoso cuál fue la que efectivamente lo causó, es decir, se sabe que solamente una actividad tenía la aptitud para detonar el perjuicio reclamado, pero, dentro del conjunto de actividades existentes, no se sabe exactamente cuál fue la que lo hizo.

Piénsese en el caso expuesto más arriba: B1, B2 y B3 van de caza al bosque y, de manera independiente el uno del otro, disparan simultáneamente sus armas de fuego, apuntando en la misma dirección. Uno de los disparos hiere a un transeúnte del sector (A), mientras que los otros dos no le alcanzan. No es posible determinar si el disparo que ha impactado en $\mathrm{A}$ fue el realizado por B1, B2 o B3, pero se sabe con claridad que fue el de alguno de estos tres.

En este caso se presenta una hipótesis de típica incertidumbre causal. Un juicio de responsabilidad no permitiría saber a quién atribuirle la obligación de indemnizar, habida cuenta del problema antes descrito.

Un segundo caso es el de la causalidad alternativa con incertidumbre en la relación entre causantes y víctimas, que se presenta cuando existe una pluralidad de causantes del daño y una pluralidad de víctimas, sin que sea posible determinar qué agente le ha causado el daño a qué víctima, aun cuando es claro que no ha sido uno de los agentes el que le ha causado el daño a todas las víctimas. ${ }^{44}$

Un caso puede ilustrarlo mejor: supóngase que cuatro farmaceutas (B1, B2, B3 y B4) han producido un medicamento defectuoso. B1 tiene una cuota del mercado del $70 \%$, mientras que los restantes tienen, cada uno, una cuota del $10 \%$. El medicamento produce daños a cien personas, sin que sea posible establecer de qué farmaceuta es el medicamento que ha adquirido cada uno de los cien afectados, aun cuando sí se sabe que no provenían todos de un mismo farmaceuta.

${ }^{44}$ Dicho de otro modo, en este caso existe "una pluralidad de causantes de daños (D1-D10) y una pluralidad de víctimas (P1-P100), pero se ignora qué causante (D) ha causado el daño a qué víctima (P)" (Martín Casals, 2011, p. 3). 
Una vez más, en cada una de las acciones elevadas por cada una de las víctimas, no será posible entonces establecer a quién se debe demandar, en la medida en que no existirá certeza sobre si su agente causal ha sido B1, B2, B3 o B4. Estos casos de incertidumbre causal son también conocidos como casos de cuota de mercado o 'market share liability', y se han difundido últimamente por cuenta de los daños irrogados por los productos confeccionados en masa.

El tercer supuesto de incertidumbre causal es el que se conoce como el caso de víctimas no identificadas. Aquí lo que sucede es que

[...] existe un agente, como la contaminación emitida por una fábrica, el principio activo de un medicamento u otro factor procedente de una fuente de riesgo similar, que incrementa el número de casos de personas que sufren una determinada enfermedad originada por factores independientes de la responsabilidad de alguien. Sabemos que hay más víctimas que antes pero no podemos saber cuáles son las víctimas que deben su dolencia a la contaminación de la fábrica. Es el caso, por ejemplo, en el que " $D$, una fábrica altamente contaminante se instala cerca de una gran ciudad en la que se producían 20 casos de cáncer al año, y lanza a la atmósfera emisiones cancerígenas no permitidas por la ley. A los cinco años de su instalación, se ha constatado que el número de casos de cáncer se ha ido incrementado de año en año y ya es de 100 . P1, P2 y P3, habitantes de esa ciudad, acuden al médico, quien les diagnostica un cáncer terminal, por lo que deciden presentar una demanda de responsabilidad civil contra la fábrica $\mathrm{D}$ por la enfermedad que sufren". Aunque, en estricto sentido, no se sabe si su cáncer es producto del riesgo ya existente con anterioridad o del incremento de casos que ha propiciado la fábrica. En fin, se encuentran los casos de incremento de riesgo. "[...] a diferencia de los casos en que se sabía que el daño de una víctima había sido causado por un ilícito civil de un miembro de un grupo de 'sospechosos' a los que pertenecía el demandado — casos (a) y (b) - o que el demandado había causado ilícitamente un daño a un grupo al que pertenece el demandante — caso (c) - esta categoría incluiría los casos en los que la incertidumbre se refiere a si un solo agente demandado (D) ha causado un daño a un solo demandante (P)". Un ejemplo lo ilustra mejor: "P nace con un grave daño cerebral. Se ignora si el daño ha sido el resultado inevitable de su nacimiento prematuro o 
ha sido causado por el tratamiento negligente del doctor D. Se establece que la probabilidad de que el daño haya sido causado por tratamiento erróneo es del 30\%”(Martín Casals, 2011, p. 3).

Nótese entonces cómo, en cualquiera de las anteriores hipótesis (a, b, c o d), lo que existe es un problema de incertidumbre causal, en el sentido de que no se puede determinar, a ciencia cierta, quién ha sido el detonante causal del daño. Frente a ella, se han adoptado dos tipos de soluciones, como se explica a continuación.

Una de ellas tiene que ver con la aplicación de la regla conocida como del "todo o nada" y la regla de la "indivisibilidad de la causa del daño". Expone Juan Manuel Prevot que

durante largo tiempo se exigió que el daño sea corolario ineluctable, directo y único de la conducta del sujeto endilgado responsable. Si bien con el transcurso del tiempo el derecho suavizó paulatinamente esta exigencia, aún perduran resabios de la misma, como, por ejemplo, la fórmula optativa del "todo o nada".

Este vetusto modo de razonar se asienta sobre dos pilares fundamentales: 1) la regla de la "indivisibilidad de la causa del daño"y 2) la exigencia de que el nexo causal sea demostrado en forma indubitable, es decir, con 'certeza absoluta'.

Como consecuencia de ello, en todos los casos en que no se logre probar fehacientemente 'el cómo y el porqué del perjuicio sufrido, esto es, mientras no surja con palmaria claridad la relación de causalidad entre la conducta del accionado y el daño reclamado por el pretensor, el reclamo indemnizatorio debe ser rechazado (Prevot, 2010, p. 151).

Puesto en otros términos, la regla del "todo o nada" exige que el grado de convicción sobre la existencia del vínculo causal sea rayano con la certeza. Cualquier resquicio de duda o de poca claridad dará al traste con la pretensión de indemnización, por ausencia de uno de los elementos estructurales de la responsabilidad.

Como es obvio, si se adopta un sistema de este tipo, el resultado al que se arriba es a que en los mencionados casos de incertidumbre causal, ante la falta de un medio probatorio que otorgue la certeza necesaria de que uno de 
los sindicados como agentes dañadores fue el causante del daño, de acuerdo con el umbral de convencimiento requerido, su pretensión indemnizatoria será desestimada, pues la alternatividad de agentes no es permitida bajo esta teoría. Los casos de causalidad incierta, por definición, son opuestos a la certeza, por lo que, bajo la regla de "todo o nada", son casos en los que no surgirá la obligación de indemnizar por ausencia de uno de los presupuestos estructurales de la responsabilidad.

Ahora bien, se le denomina regla de "todo o nada" por cuanto no admite puntos medios: o la pretensión prospera como un todo o no prospera; no hay matices; o gana el demandante o gana el demandado, según el umbral de certeza que se alcance respecto de la causalidad.

La cuestión es que una solución así puede no ser la más equitativa, comoquiera que

afirmar que, como no se puede determinar quién es el causante del daño, ninguno de los miembros de ese conjunto de personas debe responder, porque el artículo 1902 del Código Civil [análogo del artículo 2341 de la codificación colombiana] — pieza de toque de nuestro sistema de responsabilidad - exige la existencia de un nexo de causalidad entre el acto generador de responsabilidad y su autor físico, no parece que sea la solución más justa; pues llegaríamos a la paradoja de encontrarnos que la víctima de los daños causados por un individuo no determinado dentro de un grupo no tiene derecho a ser resarcida, pero sí lo tiene cuando puede identificar a su autor. Se trataría de supuestos conocidos por la doctrina como casos de causalidad alternativa, de 'culpa anónima', de causalidad incierta o 'causa anónima', que de no ser indemnizables frustrarían la finalidad del derecho de daños (Múrtula, 2006, p. 3).

La regla del "todo o nada" se la juega entonces por la justicia o la injusticia total, y, de hecho, suele colindar con esta última, porque en casos como el de la incertidumbre de agente o de relación agente-víctima, en los que se sabe que alguien ha generado el daño, pero no se sabe quién, opta por dejar a la víctima sin indemnización y, de contera, por permitir la fuga de la responsabilidad. La falta de certeza en relación con la identidad específica del agente causante del daño - independientemente de la certeza en cuanto a su causación- conduce 
a un resultado injusto y contraintuitivo: la víctima, a pesar de que padeció un perjuicio y de que es sabido que alguien se lo generó (aun cuando no se sabe quién), quedará desprovista de indemnización y su daño quedará en el aire.

La contracara, como es obvio, es que se evita así la condena de un inocente; ciertamente, al no proferir un fallo de responsabilidad, evita condenar a un sujeto que, de repente, nada tuvo que ver con el ilícito civil (por ejemplo, condenar a uno de los cazadores que no le dio a la víctima).

El problema, sin embargo, es que, como lo decíamos, esta solución enfrenta un riesgo potencial de injusticia muy alto: al no admitir un camino intermedio, lleva a que un sujeto gane todo, mientras que el otro lo pierda, lo que es contrario a ciertos principios morales que subyacen a los sistemas jurídicos de occidente, como el de equidad. Además, es una situación que genera incentivos distorsivos, comoquiera que favorece el que se adopten prácticas en las que, de consuno, los potenciales dañadores fomenten los daños anónimos, para eludir así su responsabilidad.

Pues bien, para evitar esta 'fuga de responsabilidades' en los casos de incertidumbre causal, instrumentos de derecho comparado han adoptado el criterio de la distribución proporcional en materia causal. Se trata de abrir un espacio a soluciones intermedias en las que no se juega el "todo o nada" en el juicio de causalidad, sino que se admite una condena proporcional en los casos en que existe solamente una probabilidad de que el sujeto fuera el agente causal del daño. Naturalmente, la proporción en que cada uno será condenado dependerá, en estricto sentido, de la probabilidad de que haya sido el causante del daño.

Se evita entonces de este modo que, en casos como los de la incertidumbre causal, se llegue a la absoluta exoneración de los demandados y, de contera, a la exclusión de la víctima de toda indemnización. Por el contrario, esta última podrá reclamar de cada potencial dañador la cuota que le corresponda de acuerdo con la probabilidad estadística de que fuera el causante del daño.

Una solución como la propuesta no solamente luce más equitativa —en la medida en que no deshace la pretensión de la víctima en las hipótesis en que es epistemológicamente imposible acreditar la causalidad—, sino que, además, fomenta el principio de solidaridad, comoquiera que asigna la obligación de indemnizar a los potenciales causantes, cuando estos han decidido intervenir en una determinada actividad. 
No en vano los Principios de Derecho Europeo de la Responsabilidad Civil (artículo 3:103)

proponen como solución general la denominada causalidad proporcional, es decir, una distribución del daño en proporción a la probabilidad de haberlo causado. La regla requiere que concurran los demás fundamentos de la responsabilidad (p. ej., actuación culposa o actividad que daría lugar a responsabilidad objetiva, existencia de daño resarcible, etc.) pero partiendo de que ha existido un riesgo que, en términos generales, es apto para producir el tipo de daño del que se trate, propugna por establecer la responsabilidad en función de la probabilidad de que el riesgo que ha creado el agente haya podido causar el concreto daño sufrido por la víctima (2011, p. 2).

De esta forma se busca dar lugar a soluciones más equitativas, modulando el problema al que se ve expuesta la víctima cuando se enfrenta a la regla de "todo o nada”, que, como se expuso, para la prosperidad de la pretensión indemnizatoria supone llevar al juzgador a un convencimiento más allá de cierto umbral de certeza sobre la causación del daño. ${ }^{45}$ Bajo el espectro de la fórmula propuesta, la víctima tendrá que probar el grado de probabilidad de que dicho agente sea el causante del daño, para que, a partir de ese hecho probado, el juez asigne la reparación conforme a esa estadística, sin que sea necesario un umbral mínimo al respecto.

Explica Miquel Martín Casals que, además,

la responsabilidad proporcional también intenta distribuir de una manera más equitativa los riesgos de la insolvencia. La responsabilidad por cuota del mercado, por ejemplo, parte de la idea de que cuando hay una pluralidad de fabricantes posibles causantes del daño (D1-D10) y una pluralidad de víctimas (P1-P100), y se sabe que el causante D1 no puede haber causado el daño de todas las víctimas,

\footnotetext{
${ }^{45}$ Steven Shavell indica: "In many situations there is uncertainty about causation. For example, it may not be known which manufacturer out of many sold the product that resulted in injury, or whether harm was due to the defendant firm's pollution or to background factors. The traditional approach of the law is to employ a $50 \%$ probability threshold: to hold a defendant liable if and only if the probability that the defendant was the cause of losses exceeds 50\%. More generally, the courts could employ a probability threshold t different from 50\%" (Polinsky y Shavell, 2007, pp. 162-163).
} 
no parecería justo hacerle responder del daño de todas las víctimas o de una parte sustancial de ellas simplemente por el hecho de que los otros fabricantes han dejado de operar en el mercado o son insolventes, ya que se le haría responder por un daño que se sabe a ciencia cierta que no ha causado $(2011$, p. 2).

Esto luce aún más razonable en casos en los que se trata de la distribución de productos en el mercado o del incremento de riesgos en la sociedad, como consecuencia de una actividad productiva. En estos casos, quienes intervienen en el mercado o en la actividad obtienen un provecho derivado de esta, por lo que se acompasa con las reglas de solidaridad social que, en casos de incertidumbre causal o de daños anónimos, en lugar de dejar desprotegidas a las víctimas, asuman una cuota proporcional en la causalidad, de acuerdo con la probabilidad de haber inferido el perjuicio.

Finalmente, es de resaltar que, desde la perspectiva del análisis económico del derecho, resulta más eficiente este esquema de imputación de la obligación reparatoria, a través de la probabilidad.Bajo el sistema de la regla "todo o nada", el sujeto dañador que sepa que la probabilidad de que él sea el causante del daño es menor al 80\% (que, como se mencionó, es el umbral de certeza exigido en el derecho norteamericano) nunca será responsable y por lo mismo no tendrá ningún incentivo de reducir su riesgo, dando lugar a resultados subóptimos. Por el contrario, en la medida en que bajo la regla que se propone la responsabilidad corresponda exactamente a la probabilidad de que sea el agente dañador, existe un incentivo para disminuir el riesgo y adoptar conductas más seguras, tal como si no existiera la incertidumbre sobre la causalidad.

Se evidencia cómo estas soluciones proporcionan respuestas idóneas a los problemas que la teoría de la imputación objetiva no logra solventar. Así, se construye un entramado normativo completo, con capacidad de brindarles a los diferentes interesados en la determinación causal y la imputación de un daño los instrumentos necesarios para adelantar este juicio con el mejor criterio.

\subsection{La aplicación de las soluciones propuestas en el escenario específico de la responsabilidad ambiental}

Las circunstancias en las que se configura el perjuicio ambiental, así como la envergadura de este desde el punto de vista de las víctimas y los victimarios, complejizan enormemente el análisis de la relación causa-consecuencia. 
Ciertamente, cuando a la complejidad ordinaria de la causalidad se le suma un escenario en el que la mayoría de hipótesis revelan causas concurrentes, daños anónimos y contribuciones leves, la dificultad crece exponencialmente. Habida cuenta de esta realidad, que afecta a los litigios existentes en esta materia, hoy en día se han presentado revolucionarias tendencias que matizan o morigeran el alcance de los principios tradicionales de la causalidad. ${ }^{46}$ Efectivamente, si bien el análisis preponderante aún se rige por el tradicional criterio de la causalidad adecuada, el de la responsabilidad ambiental ha sido un prolífero escenario para revelar las dehiscencias de estos parámetros y proponer doctrinas de avanzada que están ad portas de aplicarse en sede judicial, como las que se expusieron ya en párrafos precedentes y como sucintamente se reseña a continuación.

\subsubsection{La causalidad probable y las presunciones de causalidad}

El primer problema que se presenta en el escenario de la responsabilidad ambiental tiene que ver con la certeza de la causalidad. En efecto, las características particulares de esta modalidad de responsabilidad impiden, las más de las veces, conocer a ciencia cierta cuál fue la causa que desató una situación de alteración ambiental. Como es obvio, en los fenómenos naturales inciden

\footnotetext{
${ }^{46}$ Como lo asevera la doctrina, “... en materia de responsabilidad por daños al medio ambiente, la existencia o comprobación de este nexo de causalidad, cuando es exigido, es aún más difícil. La dificultad de su determinación en los daños producidos al medio ambiente es muy considerable. Es decir, muchas veces se da un mal criterio de imputación, ya que para el daño ambiental lo normal es que haya demasiadas causas determinantes del origen del suceso del daño..."(De Carvalho Leal, 2010, p. 168). El profesor Néstor Cafferatta, por su parte, explica que “... el daño ambiental contiene una problemática propia inherente a la cuestión medioambiental; cierto grado de 'incerteza' o 'incertidumbre'. Hace tiempo que, aun dentro del campo de las ciencias duras o de las ciencias de la naturaleza, se ha abandonado la idea del determinismo, de la relación de causalidad absoluta, de causalidad cierta e indubitable. A partir de la física cuántica, ha cambiado el concepto de la relación de causalidad y se ha incorporado el de azar, la estocástica. Ilia Prigogine, premio Nobel de Química en 1977, adquirió fama a nivel científico por haber incorporado al azar a la relación de causalidad.Él comenta que hemos pasado de una lógica de relación causal 'del reloj' a una lógica de relación causal 'de las nubes'. Asimismo, dice que la relación de causalidad en las ciencias de la naturaleza ha perdido el sentido lineal de causa-efecto, es decir, 'dada tal causa se produce tal efecto'. Para él, la relación de causalidad se ha transformado en una suerte de relación de causalidad circular, en virtud de la cual lo que era causa se transforma en efecto y lo que era efecto se transforma en causa. En consecuencia, si las ciencias físicas y las de la naturaleza nos están enseñando que hay que tener en cuenta elementos de incerteza, no hay razón por la cual en el ámbito de la responsabilidad por daños y, en particular, por daño ambiental, se exija una relación de causalidad absoluta, indubitable, lejos de la idea de la probabilidad" (Cafferatta, pp. 88-89).
} 
un sinnúmero de variables aleatorias que, en definitiva, impiden determinar, con relativo grado de certidumbre, la relación causa-consecuencia, incluso a la luz de postulados abstractos, que, como las máximas de la experiencia, son los indicados por la teoría de la causalidad adecuada, hoy en día imperante en materia civil. No en vano, las ciencias naturales abandonaron la renombrada teoría del determinismo.

Es, en suma, el problema de la incertidumbre causal que, con múltiples variantes (causalidad alternativa con incertidumbre en el agente, causalidad alternativa con incertidumbre en la relación agente-víctima, etc.), fue expuesto en el acápite precedente y que se materializa, fundamentalmente, cuando es objetivamente imposible determinar quién fue el causante de un determinado resultado dañoso.

La solución tradicional para estos casos es que, al no cumplirse con un determinado umbral de certeza en relación con la existencia de vínculo causal, se impone la necesidad de exonerar a todos los potenciales agentes dañadores y, de contera, privar de toda indemnización a la víctima. Así, por ejemplo, si se sabe que en una determinada región del territorio han surgido ciertos daños ambientales con ocasión del accionar de tres fábricas, pero no se sabe a ciencia cierta cuál de ellas es la que ha causado un daño en el predio específico de A, la solución ordinaria sería la de exonerar a las tres fábricas habida cuenta de la falta de certeza en relación con la existencia de relación de causalidad. La contrapartida de esta circunstancia es que A resultaría sin indemnización a pesar de que es evidente que su situación sobrevino como consecuencia del accionar de alguna de las tres empresas, lo que se traduce en una situación de injusticia, especialmente a la luz de la justicia correctiva. ¿Qué hacer entonces frente a ello?

Un primer grupo de soluciones, con fuerte presencia en el derecho comparado, ha sido el de flexibilizar y matizar la exigencia de un nexo de causalidad cierto entre la conducta imputable y el daño irrogado, comoquiera que, de mantenerse dicha exigencia, en muchas ocasiones fracasaría y se frustraría cualquier pretensión indemnizatoria en sede ambiental. Las alternativas han sido diversas: juicios de causalidad hipotética, suposiciones de causalidad, causa flexible, causa aparente, entre otras varias más.

Con todo, la tendencia mayoritaria ha abogado por dos soluciones de particular acogida, a saber: 
a) La imputación por causa probable: bajo esta tesitura, el intérprete entiende acreditada la causalidad cuando, a la luz de un examen objetivo, aparece que un comportamiento, además de idóneo para producir un resultado, fue probablemente el que, en el caso concreto, llevó a producirlo. Así, esta teoría combina dos grupos de factores: la idoneidad y la probabilidad de la causa, de manera tal que entiende configurada la causalidad cuando, en abstracto, el fenómeno cumple con el mencionado requisito de idoneidad y, en concreto, llena también la exigencia de probabilidad. En otras palabras, lo que se mira en esta tesis no es la existencia de una causa cierta, sino de una causa probable del hecho, midiendo la probabilidad de acuerdo con los postulados de idoneidad y probabilidad propiamente dicha. ${ }^{47} \mathrm{La}$ ventaja para la víctima es notable: no se le exige el encomiable y muy elaborado esfuerzo por acreditar causalidad en fenómenos ambientales, sino que le basta con llevar una cierta convicción al operador judicial, de tal suerte que este encuentre probable la causación, por ejemplo, por existir indicios suficientes o por ser razonable estimarlo así.

b) Las presunciones de causalidad: otra alternativa bastante recurrida consiste en presumir el nexo de causalidad. El efecto más importante de esta presunción, como es sabido, tiene que ver con el traslado de la carga de la prueba de la víctima al victimario. ${ }^{48}$ Por esa razón, resulta ser una estrategia muy idónea en aquellos casos en que es más fácil desvirtuar la causalidad que acreditarla. Este escenario supone entonces que a quien ha padecido un daño no le corresponderá

${ }^{47}$ Cfr. De Ángel Yágüez (2000, pp. 77 y ss.), de acuerdo con el cual, en varios ámbitos de la responsabilidad, existe "... hoy una tendencia considerable a afirmar que cuando sea imposible esperar certeza o exactitud en materia de relación de causalidad, el juez puede contentarse con la probabilidad de su existencia [...] será en ocasiones una probabilidad próxima a la certeza, o bastará en otros casos la alta probabilidad, o será suficiente contar una probabilidad de más del 50 por 100 (el principio more probable than not de la jurisprudencia norteamericana), pero en todo caso se aliviará de forma sensible la posición del demandante [...] no basta que un hecho pueda ser considerado sólo como una hipótesis posible. Entre los elementos de hecho alegados, el juez debe tener en cuenta los que le parecen más probables. Esto significa sobre todo que quien hace valer su derecho fundándose en la relación de causalidad natural entre un suceso y un daño no está obligado a demostrar esa relación con exactitud científica..."(Scartazzini, 1991, pp. 62-64). 227).

${ }^{48}$ Sobre el particular, ver Parra Quijano (2009, pp. 235-241) y Sentis Melendo (1979, pp. 144, 209, 
probar que dicho daño fue consecuencia de la conducta del victimario, sino que, por el contrario, será al demandado a quien le corresponderá probar su exoneración, esto es, la inexistencia de cualquier relación causal. La presunción, por lo demás, es una estrategia pro victimae, en la medida en que, independientemente del caso concreto, consagra una regla general a favor de quien ha padecido un daño, en el sentido de entender o presuponer configurado el nexo causal y, en esa medida, asignar la carga de probar quién resulta demandado o acusado en el proceso de responsabilidad.

Pues bien, estas dos alternativas, como se decía, han sido aplicadas en normativas foráneas, con no despreciables resultados prácticos. El problema, sin embargo, es que es una solución que puede conducir a un cuestionamiento importante de equidad: ¿por qué se matiza la exigencia de la causalidad a favor de quien ha padecido un perjuicio ambiental y no a favor de quien ha sufrido otra clase de perjuicios cuando estos también reflejan un problema de incertidumbre causal? ¿Qué acaso el perjuicio ambiental es más relevante, valedero o merece una mayor tutela que otros perjuicios de naturaleza singular? Dar una respuesta satisfactoria a estos interrogantes será sumamente dificultoso, especialmente si se tiene en cuenta que la relación de causalidad trasluce uno de los componentes moralizadores de la responsabilidad civil y, de contera, matizarla o flexibilizarla puede suponer una matización o flexibilización selectiva del componente moral de la responsabilidad para ciertos ámbitos específicos.

Por eso, debe procurarse una solución que traduzca una regla general y no una gabela particular para los casos ambientales: esa solución de estirpe general, que no conlleva la inequidad antes mencionada, es la de aceptar la regla de la proporcionalidad ya explicada en un segmento anterior. En efecto, si se supera la regla del "todo o nada" y se acepta que la imputación de responsabilidad debe hacerse bajo un esquema de probabilidad, en el que los umbrales o estándares de certeza exigidos son menores, es entonces evidente que se alcanza una regla general que, sin las inequidades de una aplicación casuista, da una respuesta satisfactoria a los casos en que parece injusto imputarle toda la responsabilidad a un solo agente dañador (porque no se sabe si ese agente fue el que causó el daño), pero también luce desproporcionado dejar sin ninguna indemnización a la víctima (comoquiera que se sabe que alguno de los agentes la dañó). 
Nótese cómo en el esquema propuesto no se trata de reducir el umbral de certeza que se exige en materia de causalidad para imputar la totalidad de la responsabilidad a uno solo de los potenciales causantes del daño, ya que eso es justamente lo que se critica por ser una inequidad propia del casuismo; no: de lo que se trata es de admitir la regla general de la causalidad proporcional en virtud de la cual, ante situaciones de incertidumbre causal (y no solo de incertidumbre causal en materia ambiental), es preciso que todos los potenciales causantes del daño respondan, pero lo hagan en proporción a criterios objetivos, como es, por ejemplo, el criterio de la probabilidad.

Así, se reitera, no se juega todo o nada a favor de la víctima o del agente dañador: no se condena a un solo agente por reducir el umbral de la causalidad, ni se priva de toda indemnización a la víctima, sino que esta última recibe una indemnización integral, solo que la recibe de cada uno de los potenciales causantes, en proporción a la probabilidad de que hayan podido causar el daño. Esta solución tiene las ventajas prácticas y de justicia a las que nos referimos en el segmento anterior.

\subsubsection{La concurrencia de contaminadores}

Otra de las hipótesis que se puede presentar en materia medioambiental es la relacionada con la concurrencia de agentes causantes del daño. En principio, en estos casos, se aplicará el artículo 2344 del Código Civil colombiano y, en esa medida, tales agentes serán solidariamente responsables por los daños irrogados, sin perjuicio de las posteriores acciones que, internamente, puedan ejercer. ${ }^{49}$

Con todo, la dificultad se presenta cuando ninguno de los agentes, individualmente considerado, habría tenido la entidad suficiente para generar el daño. En estos casos, se pregunta entonces si pueden ser condenados a indemnizar, in solidum, el perjuicio irrogado, ya que, causalmente hablando, ninguna de sus contribuciones era conditio sine qua non para llevar al resultado lesivo. Nuevamente, surgen diferentes teorías. Una de las más aconsejables y acogidas parece ser adoptar una posición que, con fundamento en la guarda colectiva del ambiente, entienda que, al quebrantarse dicha guarda por una pluralidad

\footnotetext{
${ }^{49}$ Como bien lo ha indicado la jurisprudencia, “... según el artículo 2344, cuando dos o más personas incurren en un mismo hecho ilícito responden solidariamente, así se trate de hechos instantáneos o de extensa duración. Lo que interesa para los efectos de la solidaridad no es el proceso mismo causante del daño, sino su resultado [...]"(Corte Suprema de Justicia, sentencia del 30 de abril de 1976).Cfr. sentencia del 6 de agosto de 1985. Ver, también, Valencia Zea (1950, p. 250).
} 
de contaminadores, todos ellos están llamados a indemnizar, independientemente de que su contribución causal, por sí sola, no pudiera generar el efecto indeseado. Esta posición procura salvaguardar y tutelar efectivamente el ambiente sano, a pesar de que, en ocasiones, parezca excesivo o desproporcionado.

Esta ha sido la solución adoptada por la doctrina, a cuyo juicio

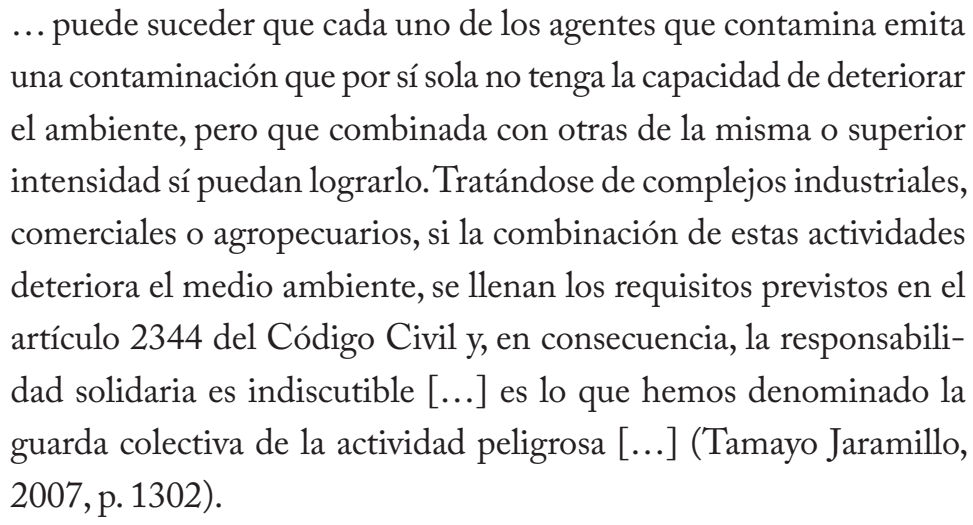

Con todo, esta solución genera los mismos inconvenientes que la aplicación irrestricta de la regla "todo o nada". Ciertamente, le impone la totalidad de la indemnización a un sujeto que, a ciencia cierta, ha sido condición necesaria pero no suficiente para la causación del daño. De este modo, conduce a una solución que desde la perspectiva de la justicia correctiva tampoco parece ser la más razonable; si la acción u omisión del sujeto no era, por sí sola, suficiente para lograr el resultado, no parece ser lo más justo que, en cualquier caso, se le condene al pago de la totalidad de la indemnización. De ahí que una regla proporcional, que considere la contribución causal del sujeto, parezca satisfacer mejor las exigencias morales que subyacen a la responsabilidad civil, evitando los conflictos a los que conduce la aplicación de la regla del "todo o nada", en los términos expuestos anteriormente.

\subsubsection{Los daños anónimos}

En fin, una tercera situación usualmente compleja tiene que ver con la imposibilidad de determinar o individualizar un agente causante del daño dentro de un grupo de posibles victimarios. En esta hipótesis, el intérprete entiende que existe una comunidad más o menos amplia de individuos potencialmente responsables, pero no puede dilucidar, en forma cierta, cuál de ellos dio inicio al curso causal que desembocó en el perjuicio. Se trata entonces de casos de 
daños anónimos o de autor desconocido, vicisitud esta última que, como es natural, dificulta enormemente la imputación de responsabilidad.

Sin embargo, en aras de no sumir en un estado de ostensible desprotección a las víctimas, los sistemas de responsabilidad ambiental han acuñado también soluciones para circunstancias como las descritas. En general, en jurisdicciones como la anglosajona, se ha propuesto extender el principio de solidaridad a todos los individuos que potencialmente causaron el daño. Así, la víctima podrá requerir la indemnización de uno cualquiera de tales sujetos, independientemente de que, en la realidad, no se conoce, a ciencia cierta, quién irrogó la lesión.

Pues bien, esta es una nueva hipótesis en la que la regla de proporcionalidad parece brindar una solución justa que evita los problemas de la aplicación a rajatabla de una regla de “todo o nada”. En virtud del sistema proporcional, se lograría que cada uno de los potenciales causantes del daño responda en proporción a la probabilidad de que haya causado el resultado, de modo tal que i) no se imponga la totalidad de la indemnización a un sujeto respecto del cual no se tiene certeza que haya causado el daño y ii) no se deje sin ninguna clase de reparación a la víctima del perjuicio cuando se sabe que esta ha padecido una lesión o menoscabo con ocasión de la situación. Esta situación es más deseable desde el punto de vista de la justicia y de la practicidad en los términos ya explicados en un acápite anterior.

\subsubsection{La labor del juez en el análisis de la causalidad}

Las anteriores reflexiones revelan que, en últimas, es al juez o al sentenciador a quien le corresponde ponderar los hechos de cada caso particular, con miras a determinar si existen o no suficientes circunstancias indicadoras de la relación causal. En este aspecto, como en los demás, no pueden sentarse reglas o cánones generales, comoquiera que la riqueza de los casos y, particularmente, de los hechos impone que el juzgador sea el llamado a determinar, cautelosa pero decididamente, si se cumplen los presupuestos de la causalidad. Para ello, debe fundarse en los criterios que provee el ordenamiento, pero también en la lógica, la intuición, la experiencia y la ciencia. ${ }^{50}$

\footnotetext{
${ }^{50}$ Como bien lo indica López Mesa, “... el juez a partir de la causalidad externa, física, demostrada, puede extremar su legítimo poder de análisis de las constancias de la causa, determinando sobre la base del
} 


\section{Conclusión}

Las consideraciones antes expuestas develan entonces el problema que existe actualmente con el vínculo causal y la necesidad de encontrar una fórmula que permita replantearlo. La sola dificultad que ofrece el nexo causal desde el punto de vista estrictamente físico o natural es ya un punto de partida suficiente para invitar a la continuidad de la revisión crítica y reflexiva sobre los criterios que son más adecuados en la práctica; del mismo modo, la experiencia comparada refleja que este es un aspecto que está lejos de ser acabado, por lo que es preciso que la academia y la jurisprudencia continúen su gestión en la construcción de teorías que sean lo suficientemente dinámicas como para compaginar con la variabilidad que ofrece la vida real.

Este escrito pretende sumarse al criterio doctrinal que se ha expuesto en la materia. Como se anunció en la introducción, en él se demostró que:

1) Las concepciones contemporáneas con las que se analiza a la relación de causalidad en el derecho colombiano resultan insuficientes y conducen, en varios casos, a soluciones irrazonables y contraintuitivas. Esto se hace especialmente patente en lo que tiene que ver con la teoría predominante, que es la denominada 'causalidad adecuada'. Al emplearse esta tesis como un criterio único de causalidad - y no como un examen de imputación que debe ser acometido justo después del estudio de la causalidad de hecho-, la causa adecuada se presta para que casos que, en justicia, debían conducir a una indemnización, aparejen realmente una exoneración. Eso es lo que sucede, por ejemplo, con las hipótesis de niños con cráneo 'cáscara de huevo' o, en general, en aquellas circunstancias en que el daño no cumple con criterios que parecieran pertenecer a otras esferas, como el de la previsibilidad.

2) Por esa razón se hace necesario repensar el esquema tradicional con el que se ha tratado la cuestión en el ordenamiento nacional. Tal vez la utilización de criterios como el de la adecuación, aunque deben preservarse, deben ser reinterpretados conforme a un nuevo esquema que permita suplir las dehiscencias identificadas. Esta reinterpretación,

sistema de la sana crítica si en ese caso ha quedado acreditada la causalidad adecuada entre el hecho del demandado y el daño de la víctima..." (2009, p. 437). 
por lo demás, ha sido realizada ya en otros países del mundo, de donde se infiere entonces que la experiencia comparada puede ser una fiable guía en la materia.

3) Como propuesta, se evidenció entonces que, en primera medida, parece aconsejable incorporar la distinción entre causalidad de hecho y causalidad de derecho. Esta dicotomía permite adoptar un examen natural de la relación causa-efecto que, con teorías como la del juicio sine qua non, efectivamente permite determinar qué suceso es el detonante de otro; del mismo modo, es una tesitura a partir de la cual se pueden restringir los excesos connaturales a la verificación meramente fáctica de la causalidad, a través de criterios de delimitación jurídica (o de selección de causas). Dentro de estos criterios, que integrarían la denominada imputación objetiva, se puede encontrar el de adecuación, el de posición de garante, el de previsibilidad, entre otros más.

4) Se demostró que esta distinción permite entonces resolver varios de los problemas a los que conduce la aplicación de la teoría de la causalidad adecuada como única teoría para resolver el dilema causal. Ahora bien, con ello no se desconoció que este tipo de tesis pueden conducir a nuevos problemas, como el de la sobredeterminación causal o la incertidumbre causal. Con todo, se plantearon algunas nuevas iniciativas para este punto, con las cuales se pretende subsanar los inconvenientes encontrados.

El objetivo, en últimas, es invitar a que se supere la parsimonia tradicional con la que se ha abordado la cuestión y se ponga sobre la mesa la necesidad de repensar, nuevamente, la teoría que se emplea en materia de causalidad. El permanecer impasibles frente a este aspecto no solamente acarrea un altísimo costo doctrinal, sino que también apareja una pérdida irrecuperable en términos de justicia, comoquiera que cada vez son más los casos en los que se depreca la posibilidad de indemnizar por la aplicación descontextualizada de la teoría de la causa adecuada.

Así las cosas, debe seguirse adelante con el debate y, lo que es más importante, adoptar posiciones crítico-reflexivas sobre el particular, ya sea para defender el estado actual o para proponer un nuevo panorama, pero, en cualquier caso, con una adecuada argumentación, que permita el debate nacional e internacional. No se puede olvidar que, como lo decía Adriano de Cupis, 
“cuanto más sobria es la intervención del legislador en la normación de la relación causal respecto a la responsabilidad civil, tanto más ardua es la función del interprete en la solución de las difíciles cuestiones que se presentan en esta materia" (1970, p. 249).

\section{Bibliografía}

Abbagnano, N. (1987). Diccionario de filosofía. Ciudad de México: Fondo de Cultura Económica.

Alexander, L. A. (1987). Causation and corrective justice: does tort law make sense? Law and Philosophy, 1.

Alterini, A. (1992). Responsabilidad civil. Madrid: Abeledo Perrot.

Baraona González, J. (2004). La cuestión causal en la responsabilidad civil extracontractual: panorama de derecho comparado. Revista Chilena de Derecho, 31.

Barnes, D. (2001). Too many probabilities: statistical evidence of tort causation. Law and Contemporary Problems, 64.

Bix, B. (2009). Diccionario de teoría jurídica. Ed. Instituto de Investigaciones Jurídicas - UNAM.

Cafferatta, N. La responsabilidad por daño ambiental.

Cárdenas Mejía,J.P.(2010). Causa extraña como eximente de responsabilidad.En M. Castro de Cifuentes (Ed.), Derechos de las obligaciones. Bogotá: Temis.

Colombia, Consejo de Estado, Sección Tercera. Sentencia del 19 de agosto de 2011.

Colombia, Consejo de Estado, Sección Tercera. Sentencia del 26 de marzo de 2009.

Colombia, Consejo de Estado, Sección Tercera. Sentencia del 5 de julio de 2012.

Colombia, Consejo de Estado, Sección Tercera. Sentencia del 9 de junio de 2010.

Colombia, Corte Suprema de Justicia, de Colombia. Sala de Casación Civil. Sentencia del 26 de septiembre de 2002.

Colombia, Corte Suprema de Justicia, Sala de Casación Civil. Sentencia del 30 de abril de 1976.

Colombia, Corte Suprema de Justicia, Sala de Casación Civil. Sentencia del 16 de mayo de 2011.

De Ángel Yágüez, R. (2000). Algunas previsiones sobre el futuro de la responsabilidad civil. 
De Carvalho Leal, V. (enero-junio, 2010). El daño ambiental y los problemas de determinación de causalidad y carga de la prueba en el régimen jurídico tradicional de reparación en España. Dourados, 2(3).

De Cupis, A. (1970). El daño. Barcelona: Bosch.

Díez-Picazo, L. (1989). Derecho de daños. Madrid: Civitas.

Díez-Picazo, L. (2007). Fundamentos de derecho patrimonial. Tomo V. Madrid: Civitas.

Engle, E. (2009). Aristotelian theory and causation: the globalization of tort. Gujarat National Law University Law Review, 3.

Gil Botero, E. (2013). La teoría de la imputación objetiva en la responsabilidad extracontractual del Estado en Colombia. En C. Bernal Pulido \& J. Fabra Zamora (Eds.), La filosofía de la responsabilidad civil. Estudios sobre los fundamentos filosófico-jurídicos de la responsabilidad civil extracontractual. Bogotá: Universidad Externado de Colombia.

Goldenberg, I. (1984). La relación de causalidad en la responsabilidad civil. Buenos Aires: Ed. Astrea.

Hinestrosa, F. (1961). Curso de obligaciones. Bogotá: Universidad Externado de Colombia.

Jourdain,P.(2014). La causalité. Recuperado de grerca.univ-rennes1.fr/.../288515_ pjourdain2.pdf

Larry, A. (1987). Causation and corrective justice: does tort law make sense? Law and Philosophy, 1.

Le Tourneau, P. (2010). La responsabilidad civil. Reimpresión. Bogotá: Legis.

López Mesa, M.J. (2009). Elementos de la responsabilidad civil. Bogotá: Editorial Universidad Javeriana.

Martín Casals, M. (2011a). La 'modernización' del derecho de la responsabilidad extracontractual. Ponencia presentada a la Asociación Española de Profesores de Derecho Civil.

Martín Casals, M. (2011b). La relación de causalidad. En Asociación Española de Profesores de Derecho Civil (Ed.), La modernización del derecho de la responsabilidad extracontractual. Barcelona: Asociación Española de Profesores de Derecho Civil.

Medina Alcoz, M. (2003). La culpa de la víctima en la producción del daño extracontractual. Madrid: Dykinson.

Múrtula, V. (2005). La responsabilidad civil por los daños causados por un miembro indeterminado de un grupo. Madrid: Dykinson. 
Navarro, I. (2013). Derecho de daños. Pamplona: Thomson Reuters.

Ordoqui Castilla, G. (2011). Principios para un derecho americano de los contratosy principios de derecho europeo de la responsabilidad civil. Bogotá: Ed. Ibáñez.

Ortiz Gómez, G. (2010). El nexo causal en la responsabilidad civil. En M. Castro de Cifuentes (Ed.), Derechos de las obligaciones. Bogotá: Temis.

Palsgraf v. Long Island Railroad Co., 248 N.Y.339, 162 N.E. 99 (N.Y.1928).

Parra Quijano,J.(2009). Manual de derecho probatorio. Bogotá: Librería Ediciones del Profesional.

Pérez Vives, A. (1992). Teoría general de las obligaciones. Bogotá: Ediciones Doctrina y Ley Ltda.

Pizarro, D. (2000). Causalidad adecuada y factores extraños. En F. Trigo Represas (Ed.), Derecho de daños. Buenos Aires: La Rocca.

Pizarro, D. (2006). Responsabilidad civil por riesgo creado y de empresa. Contractual y extracontractual. Tomo I. Buenos Aires: La Ley.

Polinsky, M., \& Shavell, S. (2007). Handbook of law and economics. North-Holland: Elsevier.

Prevot, J. (2010). El problema de la relación de causalidad en el derecho de la responsabilidad civil. Revista Chilena de Derecho Privado, (15).

Quézel-Ambrunaz, C. (mars, 2010). La causalité dans le droit de la responsabilité civile européenne. La causalité dans le droit de la responsabilité européenne. Séminaire du GERC, Géneve.

Salvador Coderch, P., \& Fernández Crende, A. (2006). Causalidad y responsabilidad. Indret - Revista para el Análisis del Derecho, 3.

Santos Ballesteros, J. (2013). Responsabilidad civil. Tomo I. Bogotá: Temis.

Scartazzini, G. (1991). Les rapports de causalité dans le droit suisse de la sécurité sociale. Basilea.

Sentis Melendo, S. (1979). La prueba. Los grandes temas del derecho probatorio. Buenos Aires: Ediciones Jurídicas Europa-América.

Solarte Rodríguez, A. (2004). Los actos ilícitos en el derecho romano. Revista Vniversitas, (107).

Spier,J. (2012). Principios de Derecho Europeo de la Responsabilidad Civil. Comentarios a la relación de causalidad. Barcelona: Thomson.

Suescún Melo,J. (2003). Derecho privado. Estudios de derecho civil y comercial contemporáneo. Tomo I. Bogotá: Legis.

Tamayo Jaramillo, J. (2007). Tratado de responsabilidad civil. Tomo I. Bogotá: Temis. 
Trigo Represas, F., \& López Mesa, M. (2011). Tratado de responsabilidad civil. Madrid: La Ley.

Valencia Zea, A. (1950). Derecho civil. Tomo III. Temis. Bogotá.

Velásquez Posada, O. (2009). Responsabilidad civil extracontractual. Bogotá:Temis. Villanueva, G. (2011). El funcionalismo y la imputación objetiva. Bogotá: Ediciones Nueva Jurídica.

Yzquierdo, M. (2001). Sistema de responsabilidad civil, contractual y extracontractual. Madrid: Dykinson. 